
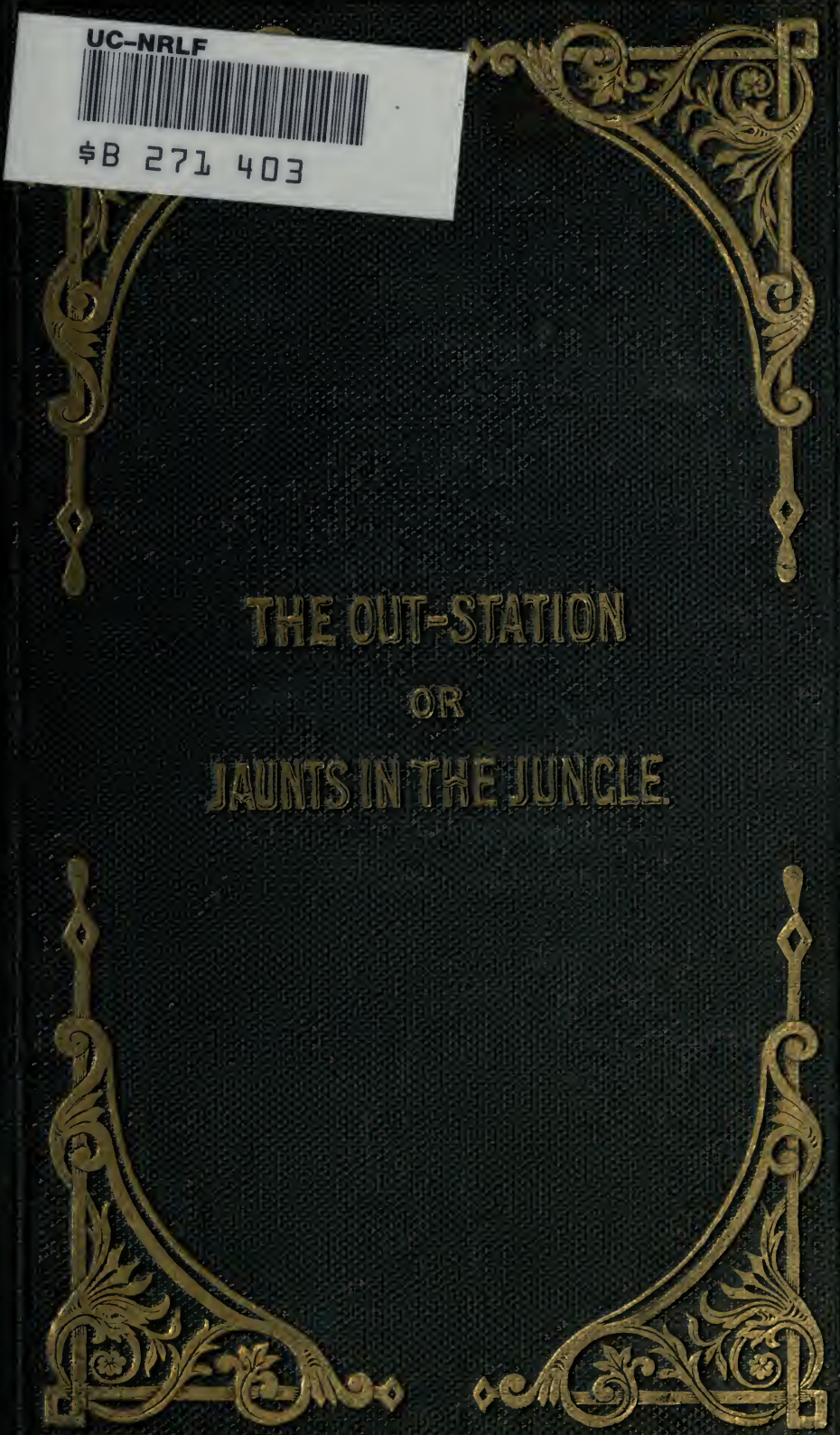

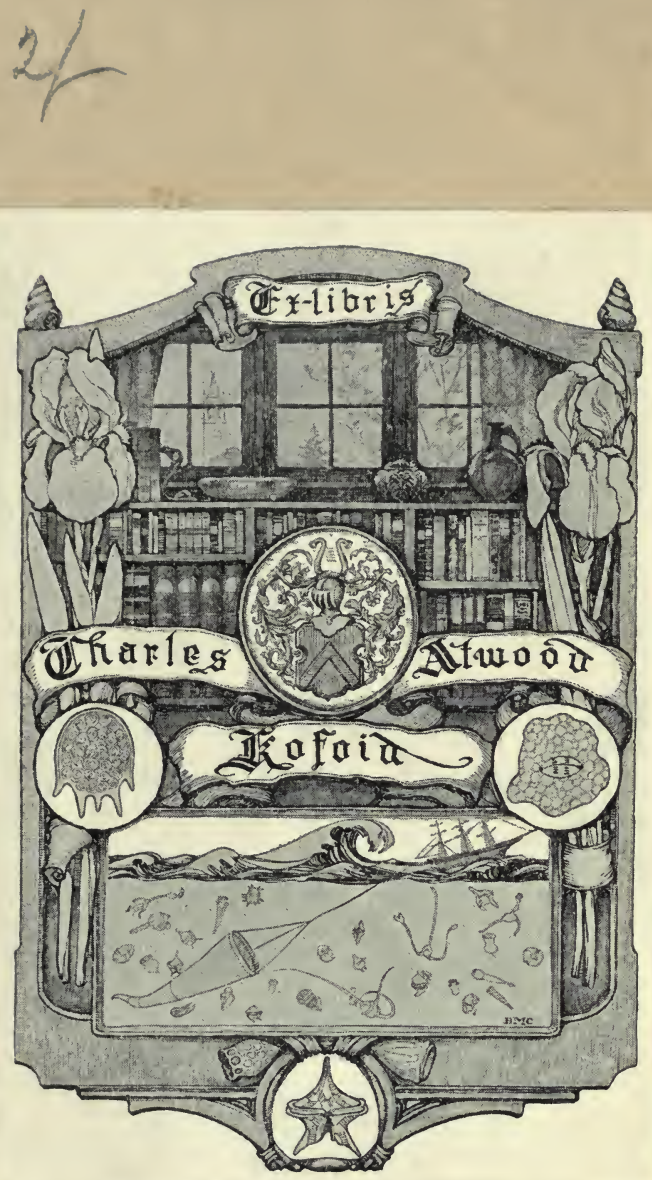


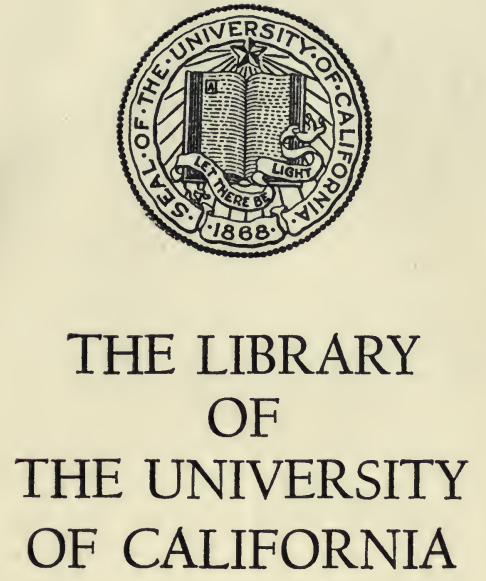

PRESENTED BY

PROF. CHARLES A. KOFOID AND MRS. PRUDENCE W. KOFOID 
Digitized by the Internet Archive in 2007 with funding from Microsoft Corporation 


\title{
THE
}

\section{O UT-STATION;}

\author{
OR,

\section{JAUNTS IN THE JUNGLE.}

\section{BY JAMES WILLYAMS GRYLLS.}

"For Liberty!

Go seek the mountain tops,

Where with the crashing pines the North-wind revels !-

Go where the Eagle and the Mammoth dwell, 'Midst mightier elements :-WHERE NATURE IS, ANd Man is not!"

Rienzi.

SECOND EDITION.

LONDON :

CHAPMA N A N HALI, 186, STRA N D. 1848. 
C. WHITING, BEAUFORT HOUSE, STRAND. 


\section{SK237 67 1848}

To

\section{H UMPHR Y W IL L YANSS, ES Q..,}

THIS LITTLE VOLUME IS DEDICATED,

AS

A TRIFLING ACKNOWLEDGMENT

OF THE DEEP DEBT OF GRATITUDE AND AFFECTION

HIS MANY KINDNESSES

HAVE ENTAILED

UPON

THE AUTHOR. 



\section{PREFACE.}

NEver for a moment dreaming of dipping into a "Preface" myself, it would be a matter of supererogation and inconsistency to inflict one, could I not turn it to the delightful use of conveying to William Harrison Ainsworth, Esq., my most sincere thanks for his kindness in permitting a re-publication of the following little sketches (originally deemed worthy of a place in "Colburn's New Monthly Magazine"); and furthermore, of making it the medium of imploring the worthy Reader-who may possibly have been sent into the world endowed with the 
vi PREFACE.

criticising temperament of a "FADLADEEN"- to bear in mind, that this, being the first bantling I have ever palmed upon Public Charity, is entitled to all the extra indulgencies usually bestowed on the happy enjoyers of Primogeniture, -an attribute that, like Charity, is universally allowed to hide a multitude of sins.

Miners' Bank,

Camborne.

February, 1848. 


\section{CONTENTS.}

CHAPTER I.

PAGE

The Mountann-Jungle of Ceylon .

CHAPTER II.

The Veddah; or, Wild Man of the Jungle ........ 14

CHAPTER III.

Dealings with the Firm of Bruin and Co.......... 22

CHAPTER IV.

A Midnight Melée with the "Unclean"............. 34

CHAPTER V.

An " Essar" on Elr................................. 43

CHAPTER VI.

A Fortaight's Excursion among the Elephants.... 55 
viii CONTENTS.

CHAPTER VII. PAGE

Major Tom Rogers of OURS-AND hIS Exploits...... 84 CHAPTER VIII.

Minor Delectabilities of Out-station Life 100 CHAPTER IX.

Disagreeabilities incident to Jungle Existence... 113 CHAPTER $\mathrm{X}$.

A "Pleasant Voyage" 128

CHAPTER XI.

"War to the Knife" with the Pearl Oysters of ARIPO.................................................. 140

CHAPTER XII.

Conclusion 


\section{THE OUT-STATION;}

OR,

\section{JAUNTS IN THE JUNGLE.}

\section{CHAPTER I.}

THE MOUNTAIN-JUNGLE OF CEYLON.

Have you not, times without number,-most amiable and unsophisticated reader,-alighted upon some of the innumerable home-conceived fancies of the Eastern jungle, imposed upon you through portions of our "Annual" curiosities of literature?-and, consequently, have you not had that interesting locality daguerreotyped on your imagination, as being an unbounded ocean of solar-microscopically-magnified herbage-each blade of grass resembling that of a gigantic broadsword-with three or four palm, talipot, or cocoa-nut trees (for all the world like parasols with handles on the "malle elastique" principle), thrown in by way of variety; whilst the terrestrial portion of the scene is garnished with the head of a tiger, and set off with a rattlesnake's tail, by way of excitement?-all which original conception 
holds about as apt a similitude to the glorious reality, as a pauper at a parish Union door to a Peri at the gates of Paradise.

Let me proceed, therefore, in the first place, to attempt the operation of a "dissolving view" on the aforesaid mental daguerreotype; and if a change does not come over the ideas of my "compagnon d'aventure," as we ramble together through the splendid mountain scenery of Ceylon, it must either be attributed to a deficiency in the descriptive faculties of the operator, or the obtuse and unimaginative temperament of the worthy reader's self.

To keep perturbed nigger spirits in proper awe and subjection to her Majesty, and "those in authority under her," for the consideration of "five shillings and threepence" per diem, and to trust to Providence and a double-barrel for one's daily bread, during two entire years of mortal existence, is an event not reserved for

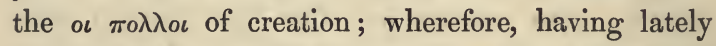
undergone the ordeal with considerable credit to her Majesty's service (although never actually congratulated on such an event by the Horse Guards), I will generously share the benefit of my experience with the reader, and doffing for the nonce the "regulation harness," invite him to spend a month with me in the jungle, undertaking to find him in unlimited 'rack punch, and in cheroots grown under my own tillage, and manufactured on my own gun-case; and should he decline to add his own contribution to the pea- 
fowl soup, the venison stew, or the snipe curry, I further guarantee to keep him from starvation, on condition that he puts up with the "cuisineries" of my Malay factotum, and allows his lively imagination to fancy he perceives in the "nigger's" desperate attempts at stews, grills, and broils, the nascent genius of a Soyer.

It is still night and darkness. Awaking to a strong smell of coffee and a state of half-consciousness, the first reflection that dawns on the intellect is the insane resolve, over champagne and claret at mess the previous night, to leave Kandy next day, at four in the morning.

Around, the Coolies are fighting and scrambling as to who shall carry the lightest package of the commissariat department, and in a state of mind any thing but angelic, having kicked the lazy, extortionate convoy (did a real nigger ever yet go to Heaven?) out of the house with their respective loads, I swallow the milkless decoction (supposed to be coffee), and lighting a cheroot to counteract the effects of a dense fog, start on my first day's journey through the precipitous scenery between Kandy and Newera Ellia.

The plain to be traversed before getting out of the town, was once the scene of the old Malabar monarchs' ideas of regal pleasures and delectabilities.

$$
\text { B } 2
$$


- Seated in the balcony of the temple that stands on it, their chief delight consisted in watching elephants (who had been specially instructed for the purpose) dissect some unfortunate law-breaker piecemeal, beginning at the finger-joints ; in looking at mothers cutting off their children's heads, and then pounding them in a wooden mortar ; and other "eccentricities," which are handed down to posterity by rude paintings of the events on the inner walls of the temple.

There is another incident attached to this temple, which is any thing but consolatory to an Englishman's amour propre. It is supposed that the drums of her Majesty's - - regiment, taken by the Cingalese at a massacre of the British troops, are preserved in one of the rooms; and, although the island has been totally subdued since, no attempt has been made to rescue the unfortunate drum-prisoners (whose nerves by this time must be somewhat unstrung) from their luckless fate ; except on one occasion by a handful of private soldiers, who having more esprit $d u$ corps (or, possibly, esprit d'arrack) in them than allowed by the rules and regulations of the Articles of War, were doubtless regaled with a dose of extradrill afterwards for their too patriotic temerity.

The route now lies over a continual series of mountain-passes through the interior, at the end of every ten or twelve miles of which is erected a rest-house, kept by some enterprising native, formerly most probably a mess-waiter, or butler under some English- 
man, whose tastes he is au fait at suiting; consequently, among his stock of rice-cakes, eggs, fowls, arrack, \&c., he not unfrequently is able to produce that inestimable luxury, under such circumstances, to the famished traveller-a bottle or two of bitter ale (surgit amari a-liquid); and vastly do I commiserate the digestive powers of a man that do not allow him an appetite at every ten miles, inhaling, as he does, a fresh, fragrant, breeze that counteracts the too powerful influence of a mid-day sun, and sets into commotion a wilderness of foliage and lemongrass, whose rustling, added to the now swelling, now scarcely audible, roar of the water-falls, as they leap from rock to rock into the stupendous precipices below, is the sole sound that disturbs the silence of a scene as bright and cloudless as ever dawned on Eden.

After passing through thirty miles of this wild and beautiful scenery, Newera Ellia-a plain on the summit of the highest mountains in Ceylon-studded with its " cottages ornées," the property of the potentates of the island's civil service, appears in sight; - an oasis in which one can revel in an English climate, feel once more the comfort of a long-abandoned woollen wardrobe, and enjoy a bottle of wine that has not undergone the refrigerating process for two hours before dinner; but our destination lies beyond this, for although an elephant now and then frightens the inhabitants of this rus in nube out of 
their propriety by paying them an angel's visit, yet it is seldom that they intrude upon the ground where their unceasing persecutor, man, has left his footmark.

Leaving the plain, and passing through three or four miles of forest, the most magnificent panorama of explored creation bursts suddenly upon the view ; plain, precipice, mountains, torrents, lying before, below, and around, as far as mortal eye can penetrate.

In front, - stretch the never-ending plains around Wilson Bungalow (built by General Sir John Wilson, from whom it derives its appellation), the walls of which one can just perceive, glittering like a white speck on the face of ocean. The vast plains around, where many a "tantivy" has cheered on a pack of English stag-hounds, having been the scene of some of the happiest days of the exiled fox-hunter.

The waters of the Megalöia are roaring in the distance, whilst the hills, covered to their very apex with apparently impermeable foliage, become a source of wonderment and speculation as to how many hundreds of hogs, deer, elephants, monkeys, snakes, and buffaloes, their branches may shelter.

Groves of guava-trees line our road, and few things in life do I know more delicious than a morning's amusement among this most exquisite fruit, whilst it is yet cold from the night air. The flavour is that of every fruit of an English garden concentrated to 
an essence, and many are the petits verres that an uncontrollable indulgence of these little irresistibilities compel their suicidal victim to undergo before breakfast.

Having arrived (after more perils by water than by land, for there being few or no bridges, the torrents must be forded as best they can, which feat is generally performed on the back of one of the coolies, whilst the horses are being swum across in some deeper and smoother part) at the base of Kamounakooli, whose summit stands 10,000 feet above the sea's level, we pitch our tent, or rather take possession of a dilapidated habitation at the foot of the mountain, every room of which presents unmistakeable symptoms that the right to its occupation will, ere long, be contested by disputants, winged, quadruped, biped, and reptile. With this latter enemy a pitched battle ensues on the spot, a long and undisputed residence in the thatch of the house having given it a "prior claim."

These nuisances, the ratsnakes, which generally average from six to twelve feet long, are perfectly innocuous, and live in the thatched roofs of almost every Ceylon bungalow, which they keep clear of rats by living on them; but whether the remedy is not worse than the disease is entirely a matter of opinion or antipathy, for in pursuit of their game the snakes not unfrequently miss their hold; and, there being no ceilings, they come down on one's head or 
bed without the least ceremony in the world; a proceeding considerably subversive to the philosophy of the "lord of creation," and resulting in an immediate onslaught on the aggressor, who, independently of this, is no doubt the most incommoded party in the first instance.

Should the natives of the country, however, (for even in these mountains there are human beings stowed away in some seemingly inexplorable and invisible recess ; living without the assistance of the "circulating medium," (and consequently little troubled with "currency questions,") Heaven only knows on what and how!) gain intelligence of the forthcoming visit of an Englishman, the greatest compliment they can show is to denude their own limbs of their white sheets to hang round the walls of the room, so that you only see the struggles of the fallen viper at the top, where, hanging over you like the sword of Damocles, he keeps you in a continual state of perspiration, if not alarm.

To settle down to sleep for the first time in life, surrounded only by savages and wild beasts of every description, a hundred miles or more distant from even the jungle-dwelling of a countryman, has more excitement in it, than one who has never experienced the situation would imagine; and it is extraordinary how the value of every thing bearing the remotest vestige of civilisation, even down to the flavour of a cigar, is enhanced thereby; consequently, about the 
most difficult business of the twenty-four hours in a jungle expedition consists in summoning sufficient resolution to "turn in." Another jorum of arrack punch, a fresh bottle of Lafitte, or "just one more cigar," however delectable at the time, generally entail an unpleasant re-action in the morning, when the nigger, as in duty bound, awakes you at five A.M., with the information that there is a herd of wild elephants or buffaloes within half a mile of the house, adding, by way of consolation, "plenty savage, master!"

There are, however, other and more potent causes that keep one under arms during the first night, or at least the greater part of it; for there being no doors or windows, and the previous tenants, out for the day, not yet being aware of a new occupant, it might be attended with disagreeable results to be caught napping by a bear with a sore head, or an unamiable wild hog wrought into a determination of going its whole self.

But now for the jungle and its denizens.

Carrying a double-barrelled gun, and my Malay follower being armed with another, more for the sake of protection than aggression (for the first day shall be devoted to a specimen of the locale of our future exploits), we commence our ascent up the mountain before the sun has shed a ray upon its summit-now clambering up huge masses of rock between immense banyan trees, whose branches, growing downwards 
again into the earth from their parent stem, prove of no slight assistance in the ascent, now suddenly emerging into open spaces of ground, covered at intervals with lemon-grass reaching far above our heads; -all the while kept on the constant look-out for squalls; the screechings of the awalkening animals over head becoming more frequent as the twilight of morning becomes more palpable.

A dark, indefinable patch, a few yards distant, just appearing above the lemon-grass, is formed by a herd of a dozen elephants, as noiseless and motionless as the old blackener stumps of trees close to them, and many an inexperienced hand has walked into an animal's proboscis before discovering his mistake.

At the next step I incontinently break in upon the slumbers of a noble elk, who, drawing himself to his full height, stares for a moment at his intruder, and then dashes down the steep as if it were a grassy flat.

Jungle fowl rise at my feet at every turning, whilst above, an unceasing clatter of tongues and creaking of branches, as the squatters thereon migrate from tree to tree, give indication that our invasion of the monkeys' territory is not viewed with any feeling of hospitality by the tribe.

A "rogue" elephant, a rascal who has been driven from his herd for habitual misconduct, and whose paw is in consequence against man and beast, next makes his appearance in front, sending us round some half a mile out of the direct road, simply because I am 
determined not to commence hostilities till the morrow ("Honi soit qui mal y pense"); and, after a twohours' pull, the welcome summit of the mountain is reached, in time to behold the sun rise from the eastern sea in "one unclouded blaze of living light."

Wiping the perspiration from my brow, I bring myself to an anchor on the top of some inviting rock, to contemplate a scene, the intense grandeur and beauty of which would absorb every sense and feeling, did not a huge cobra di capella at the moment, lifting his hooded head from one of the fissures of my adopted throne, send me sprawling among the grass and brambles at its foot. A load of "No. 7 " shot soon avenges my insulted dignity and interrupted contemplation, and uncoils twelve feet of the deadliest of the viper tribe.

At the report of the gun, flocks of diminutive parrots of every imaginable hue spring from the branches below; minute birds of Paradise, with their two streaming tail feathers, whirl over head, and

Strange things come up to look at us, The monsters of the woods.

In such a scene-miles and miles away from the mark of human hand, where, perhaps, one can only see in its full force the truth of

How beautiful is all this visible world, How glorious in its action and itself,

where, a human speck, we stand alone amid the 
habitations of the hugest and deadliest of the brute creation, who take no thought of the morrow, what they shall eat or what they shall drink-in such a scene, I say, it is strange to recur for a moment to the busy, idle, laughing, weeping, glittering, squalid, hoping, despairing, struggling world of our fatherland!

"Where is the world at eighty?" says Young; where is it at eighteen? he might have asked, standing on the mountain jungle of Ceylon-passed from existence, almost from memory! But "every man his own philosopher"-I won't apostrophise.

As the sun gets higher the signs of life gradually disappear, till the parti-coloured lizards alone seem to have it all to themselves.

Now and then a brilliant, harmless, snake rustles through the dead grass, and at intervals, a peacock, in all the majesty of a seven-foot tail, stalks out of the skirt of the jungle; but, by degrees, even these vanish, until nothing is left to disturb the silence of a tropical noonday, the intense stillness of which it is almost painful to endure.

Such a picture of nature in its primal state, unruffled by a breath, unclouded by a haze, admits not of description.

But it is not always thus.

Dark, destruction-charged, and terrible, are the hurricanes that sweep at times over the scene. Through the deep ravines around, the gusts of wind, like yell- 
ing fiends, howl and shriek in dismal chorus, falling on the ear with an ominous sound, woeful, unearthly, and desolate, as of yore they struck upon the senses of the lonely dwellers on Mount Ararat, seeming to moan over the destruction of a world !

At last comes night-cloudless, brilliant, and fairylike in its moonlit existence.

The white mists rising in the valleys below, give to the hill-tops that stretch above them the appearance of a cluster of islands in a silvery sea. Myriads of fire-flies glitter on every tree of the mountain, and never did a glimpse of Paradise beam on the opiumwrought visions of a fanatic in all the beau-ideal of its blest tranquillity more serenely glorious than the scene before me!

At length a shriek from some dyspeptic baboon in a nightmare recalls a sense of my position, and the late hour of night ; and the last cheroot,

Like a saint of old, condemn'd and sold, To death through suffering driven;

having

Pass'd with a smile, from its funeral pile,

To become a bright cloud in Heav'n,

I retrace my steps to my mountain-home, and am soon wrapt in a sleep as breathless as the air around. me, and dreamless as the sleep of death ! 


\section{CHAPTER II.}

THE VEDDAH; OR, WILD MAN OF THE JUNGLE.

Although not strictly catalogued amongst jungle game (inasmuch as they are human beings), I must indulge the reader with my introduction to the Veddah, and the first interview with this wild man of the jungle.

Not quite a century ago, when this tribe-who may be said to constitute the gipsies of Ceylonbecame rather too numerous and predatory in any particular locality, leave was always granted by the reigning monarch to his subjects inhabiting the overrun district, to have a month or six weeks' shooting among these poor wretches (making game of them with a vengeance); and even within the last dozen years, a similar request was made to the then governor of the island, Sir R. W. Horton, by a deputation from the interior, and his refusal to support the "vested rights" of these amiable niggers caused no small degree of dissatisfaction amongst them. 
Without any other habitation than the thickset branches of the nearest tree, the Veddah lives principally on wild honey and raw deer-flesh. In fact, nothing comes amiss to its digestion : and whether it really is a human being, or not, is with many an open question to the present time; although the fact of its constructing bows and arrows for the purpose of slaughter, would argue in favour of the former supposition.

The bow they make use of never exceeds eighteen inches in length, whilst the arrow scarcely exceeds a foot, and with this dimunitive weapon, which is generally poisoned-they pick off a deer at full gallop, sending in the shaft behind the shoulder, and piercing the heart; but more generally, ensconced in their roosting-places, they await the arrival of the unsuspecting victim, to sleep or feed just beneath them, and then quietly sending a shaft into a vital part, are stocked with venison for a week.

Clothes of any description they abjure, in place of which both men and women are entirely covered with pile, whilst the profuse locks of both sexes, reaching below the knees, form a complete shelter to them from rain or sun.

On what terms of intimacy and friendship they stand with the next degenerated specimen in the family of Creation - the ourang-outang-it was never my good fortune to discover; but often have $I$ in some of my jaunts in the jungle, in search of a dinner 
or a pair of tusks, come upon a party of half-a-dozen Veddahs, and sent them scampering off in mortal dread of their lives, and chattering for all the world like so many apes.

On one occasion, having penetrated further than usual into the jungle, where I had followed the recent track of a herd of elephants, I suddenly pounced upon a party of Veddahs at feeding time. Having established their "salle-à-manger" in a corner of a ravine with high rocks all around them, except at the spot where I made my unwelcome appearance, there was no possibility of escape.

Entertaining for a moment a doubt on my own part (in which my Malay gun-carrier evidently joined me), whether it would not be more prudent to exercise the better part of valour, and cut and run as fast as my legs would carry me (after a very brief apology for the intrusion), my resolution to remain was decided by witnessing the superlative state of alarm into which we had thrown the dinner-party. Some began to jabber and screech, others to bury their faces in the grass, whilst one or two stared stupidly at us, thinking, no doubt, that their hour was come, and possibly the arch-enemy also (for niggers always paint him white) to square accounts with them.

There was one old fellow amongst them, whose hairs were quite grey, and whose looks were more pacific and less perturbed than the others, and to him I first addressed myself by every imaginable sign and 
gesture, but he either could not or would not understand; so the next resource I had recourse to was turning out the contents of my pockets-every body knows the heterogeneous variety of merchandise contained in a shooting-coat pocket-and by dint of coaxing the old man, and offering him one thing after the other, I so far gained his confidence as to get near him, although it was very much in the same manner that one would approach a sulky mastiff; but, as luck would have it, the article that settled the business, and gained us the whole tribe's good will in a fixity of tenure, was the brass regimental whistle and chain which the Malay - a corporal in the Ceylon rifles-had luckily brought with him.

No sooner did the patriarchal Veddah understand how to make it send forth a squeak, than his delight became unbounded; he grinned demoniacal gratification, and the chief difficulty now seemed to consist in ever getting him to leave off.

The others, gaining courage, one by one began to gather round him, and, remaining at some little distance, I had a chance of thoroughly observing this singular and outcast tribe of people, of whom there were present four men and two women.

Whether it was the overpowering melody of the screeching brass, or my own very amicable and assuring demeanour, that imparted fresh courage, I cannot say, but in a very short space of time the remaining five were all cringing round, and pawing us, 
no doubt expressing their ardent desire to be straightway put in possession of a whistle apiece.

Now to let them off unsatisfied, particularly as I wanted to make use of their services, was not the policy to be pursued; so one fellow was presented with my powder-flask (first securing its contents myself) which he forthwith commenced trying to whistle through, and is no doubt trying it on still.

One of the "fair sex" had my neckerchief, and the other my pocket-handkerchief, which, being of very bright patterns, no doubt enthroned me in their hearts for ever.

This was paying rather dearly, however, "for our whistle."

One fellow, more importunate than the others, tinished the brandy flask, and got as drunk as an owl; and so after having received the most friendly assurances from these foreign powers, I proceeded to obtain all the information to be got out of them relative to the locality of the elephants.

Pointing to the tracks of these animals, which every here and there were fresh, and then lost among the grass and underwood, I made them understand what I wanted; and although I was more than once nearly led into a personal quarrel with the old gentleman, owing to whether the whistle should be blown or not during our search for the animals, they accompanied-or rather guided-us so far that a crash of breaking branches gave notice that we were close on 
our game; and the next moment our cicerones had scampered pell-mell up into the nearest tree, where the old brute immediately began whistling as loud as his lungs would allow him, by which means I certainly lost a first-rate chance of flooring a splendid tusk elephant.

By a chance shot, however, I sent a ball into the temple of the last of the fugitive beasts as he trotted past, and without a struggle or a groan the monster sank down silently, dead upon the grass, with an ounce bullet in his brain.

It was some minutes before I could see any signs of my new acquaintances, the Veddahs; the contiguity of the elephants, and the report of the gun, no doubt kept them silent, but when they espied the prostrate carcase, and the Malay and myself seated upon it, they came forward with the most frantic yelling, and grotesque dances imaginable ; in short, I would not have given sixpence for Buddha's chance of notice, had he put in a sudden appearance, so intense was their adoration of us.

This was getting by degrees too enthusiastic to be pleasant, consequently, as soon as we conveniently could, we made our exit, leaving the Veddahs to the dead elephant and their own excited imaginations.

Never having witnessed the Bosjesmans, or the late enterprising Mr. Harvey Leach's personation of "What is it?" I cannot say how nearly either of them assimilated to the Veddah, but weighing these c. 2 
uncivilised beings with civilised baboons, they drop prodigiously in the scale of "social etiquette."

Who is there that lived in Ceylon about the year 1832 that does not remember Esau?

Poor Esau!-at last a victim to civilisation and a taste for cognac!

Esau was a baboon, the property of Dr. — , of the staff. Although in height somewhat under the military standard (being between four and five feet), Esau gloried in scarlet and gold, and not unfrequently in a sword; but although he served, as will presently be seen, to "point a moral," unfortunately he could boast of no attribute whereby to "adorn a tail."

This extraordinary animal received an education that would have made him an ornament to society in general - if he held his tongue.

When Dr. — dined at home, Esau invariably sat down to dinner with him, helping himself to what he preferred like a Christian ; and although at first a strong innate conviction on his part that fingers were made before knives and forks caused some slight misunderstanding, Esau at last gave in, and used these seemingly superfluous articles.

Ask Esau to take wine, and he would give you a bow and grin worthy of a Gaul.

Now it is not likely that such an original and entertaining character would be kept long out of the congenial clime and company of a mess-room (Reader 
in red! don't think me personal); so Mr. Esau used to come in with the dessert and go out with the small hours.

At first he was contented with claret, but progressively advancing in the scale of sociality and wisdom, he imbibed the same idea as that entertained by respectable old Sam Johnson, that "claret was made for boys, port for men, and brandy for heroes," so to cognac he came, and as sure as the night arrived, Mr. Esau was "as drunk as a lord."

To make an end of it.

Dr. — 's surgery-door, as fate would have it, was one day inadvertently left open, and in his pursuit of knowledge under difficulties, Esau took advantage of the circumstance to dip into the mysteries and hieroglyphics of pharmacy.

But man will err, and why not a monkey?Green, pink, blue, and crimson coloured bottles might have excited, curiosity, but they were left untasted. One large plain glass bottle did all the mischief, it contained a fluid resembling in colour British brandy, and that was quite sufficient for Esau.

Without stopping to smell, the poor fellow finished half the bottle at the first pull, and made his exit from the troublous scene of life with half a pint of laudanum in his interior; leaving behind him a name that will long be remembered by those that knew him, and a moral to man and monkey to avoid British brandy. 


\section{CHAPTER III.}

DEALINGS WITH THE FIRM OF BRUIN AND CO.

For my own part, I always entertained a very decided penchant for the whole bruin family, individually and collectively.

Whether it was the off-hand affectionate greeting with which they were ever ready to welcome a stranger (although, unfortunately, like that of the amiable youth, Manfred, their "embrace is fatal"), or the bluff, stolid, pig-headed, John Bullish way they possessed of "doing business," that won my affections, is of no possible consequence to the reader. Suffice it to say, that I own, unblushingly, the soft impeachment; and very seldom ever put myself out of the way to murder in cold blood one of the innocents.

Our major abominated-or, more bruinically speaking, could not bear the bare idea of-bears.

How far he was justified in his antipathy, remains to be read, and, as it constituted my first expedition 
against this "downy" tribe, is, perhaps, worth the chronicling.

It was tiffin (i.e., luncheon) time in the garrison of - $\longrightarrow$, in Ceylon; that long anticipated glorious hour of the twenty-four, which proclaims the eight interminable ones following the morning's parade to be knocked on the head for that day at leastthose hours so vividly remembered, in which, like miserable ghosts, the dwellers in barracks wander forlornly up and down the corridors, puffing Manilla cheroots, desperately asking every body they momentarily encounter "what o'clock it is,"-and bullying the messman because it is not an hour later; sighing for "two, P.M. ;" as if it were the moment they had lived all their lives to survive and be millenium-ized!

It was tiffin time, and a dozen of us had tallyho'd the first mess-waiter with the first dish of curry into the mess-room, when the major (who, bless his old soul! is now quartered in Heaven) made his appearance at table among us ("his boys," as he used to call us), bearing on his shoulders a physiognomy-

Eheu ! tantum mutatus ab illo!

in which he had left us the night before, as to make it evident that there was a screw loose : and it was not until the worthy old soul had drained a tumbler full of "claret cup" at a draft (a compound, good reader! of claret, mint, sugar, and nutmeg, iced- 
try it, if you are ignorant of the quality), that we could get the remotest inkling as to how the jolly countenance of that religious devotee to Bacchus could be so "sicklied o'er with the pale cast of thought."

But the major shall tell his own story-the first and last dealings he ever had with the Firm of Bruin and $\mathrm{Co}$.

"By Jove! my boys! it is a lucky chance you see your old major among you again!"

"How so, major?-Do tell us!"- exclaimed a dozen tiffin-eaters, in a voice as clear as consternation at the prospect of so unwished for a consummation, and a spoonful of doubled cayenned mulligatawney would permit._-"You look as if you had seen a spirit!"

"I tell you what, it's nothing to laugh at!-If it had not been for a spirit of a very different description, I should have been as dead as that kabob curry! I started home last night" (the major's bungalow was two miles distant from the mess-house), "or rather this morning-when was it, messman, you gave me that bottle of brandy?"

"Four 'clock 'morning, master!"-answered the messman, looking very tired, and a shade or two blacker than usual.

"Pooh! nonsense!-Well, I had no sooner got out of the fort gates than I knew something would happen to me. I never pass that clump of cocoa-nut trees without a presentiment, and last night my worst 
fears were realised. Before I had gone a mile, what should I see standing directly in my way home, but a huge brute of a bear! half as big as an elephant, and black as the devil himself! Before I had time to run, or to plan any mode of attack, he was upon me! I had no weapon of any kind near me except my fists, so I was obliged to grapple him by the snout with one hand, and punch him in the ribs with the other; but he was too much for me, I felt myself going, and at the very moment that I thought 'twas all up, and tried to remember some of my catechism, (God forgive me!) I recollected the bottle of brandy I had in my coat-pocket, carrying home with me !

"By a desperate effort I got one hand free, and managed to extract the bottle; and with the last remaining ounce of strength left in my carcass, I smashed it over the head and eyes of the enemy!-By the god of war, boys, you should have seen the fellow hop about as the fiery liquid trickled into its eyeballs !

"It saved my life :-and saved you, you rascals! a funeral parade this evening!-Claret, messman!"-

"Time to think of one's bier when bruin hops!" exclaimed the most inveterate, irredeemable punster of the regiment, whose diabolical sallies at wit were invariably greeted with a yell of execration from the auditory; -in the present instance particularly loud from the major; of whose story it had utterly destroyed the romance, as well as annihilating all sympathy for the narrator. 
(By way of parenthesis, I must be allowed to relate an anecdote of this same punning wag.

One of the big-wigs of the island passed half his time in collecting antiquities (a sort of virtuoso was he in every thing, from a starved fire-fly to a triangular cocoa-nut), varied in their degrees of mouldiness and curiosity.

One sanctum, and a tolerably large one it was, was devoted to the purpose of an inanimate menagerie, which one fine morning received an addition from our friend in the shape of a "Muscovite" chair.

The donor was asked to dinners and suppers innumerable on the strength of the gift, and it was upwards of a year before the old gentleman found out that the only claim the chair could adduce to being a Muscovite, lay in the fact of its being a "Rush 'un."

However, the perpetrator of the joke had not to stand the brunt of the discovery, for he was 14,000 miles away, and of course the Rush'un soon found its Siberia in the kitchen.)

But to return to our bears.

The seriousness with which our brother officer told the bear story, left no doubt on the minds of any present, that, at all events, it was "founded in fact," and revenge and brandy-paunee simultaneously inflaming the party, it was agreed before 5 P.M., to inflict summary chastisement on this ursine highwayman, so away we sallied, armed with guns, rifles, \&c., headed by the major, with a brace of horse-pistols. 
Many of us had then never seen a wild bear, and our excitement being intense, we had invested the creature with a thousand more terrible attributes than ever entered into the compositions of all the bears since they disembarked after the Flood; and if it had not been for the extra glasses of "fire-water" that we swallowed before leaving table, at the possibility of falling a victim to bruin's killing affection, we cannot possibly give a notion of what the state of our nerves would have been, when the major, throwing up one hand in the air (with the pistol in it) to enjoin silence, came to a dead stop, and in a sort of articulation between a whisper and a groan, ejaculated-

"Here's the very spot!"

For hours did we in vain explore every hole and corner, now looking up among the cocoa-nuts, and then down into the rat and snake holes, but there was not a vestige left, not even the ghost of a footmark.

After a very considerable space of time, as we were starting on our way back to barracks, one of the party stumbled across the stump of an old tree, around which a fire had evidently once been lighted, which had left it perfectly black; and between two small branches, sticking invitingly out at the top, we undoubtedly did discover the neck of a recently-broken black bottle, the other part of which lay in fragments around.

The tree altogether had a disagreeably strong per- 
fume of cognac about it, and was terrifically mauled and wounded where the bottle lay.

But we didn't find the bear.

It was some months after the event above narrated, that I found myself brought into active service and actual collision against bruin and his firm.

A Cingalese one day came to the bungalow with a most lamentable tale about a bear having invaded the generally peaceful neighbourhood of his habitation, where it had devoured his tortoiseshell comb (an ornament which all the natives, male and female, use to keep up their "back hair," and on which they set a high value), rooted up all his betel-nut, and finished by gobbling down his remaining stock of rice and his youngest boy.

Having at times experienced the hospitality of the man when on a shooting excursion (and, moreover, having a huge desire to send home a bear-skin rug for the very prettiest and smallest foot in creation to pillow itself upon), I resolved to start next morning by daylight, and encounter the embrace of the ruffian, or as domestic tragedy heroes say, "to perish in the attempt."

And now, courageous reader, I shall depend on your company and assistance, and if you see me folded in the animal's embrace, do not be in a hurry:- 
come close up to him-quietly insinuate the muzzle of your gun into his ear, or as near it as you like to advance, and then pull steadily.

You may depend on my doing the same good office for yourself, should he show a partiality for you.

Let me give you another hint.

As soon as he shows fight, and before he attempts to hug you, he will get on his hind legs, and looking you straight in the face, begin to grin and dance in the most grotesque manner imaginable.

In this way he will approach you nearer and nearer at every step, until he gets within closing distance ; keep your charge till then; and when he thinks he has you in his arms, find your way to his heart without a moment's delay.

Having thus far instructed you, let us put our theory into practice.

Leaving our bed, and accompanied by a servant, carrying breakfast, we depart to the scene of action.

Living-as we suppose ourselves to do-at an outstation, we are soon in the wilderness of the jungle, scrambling down mountain-roads, formed by sudden torrents after heavy rains on the hills, and anon reaching the shelving sands of some broad river, whose clear and motionless surface induces us to take a refreshing plunge before we go further, by way of shaking off whatever drowsiness remains, and of giving us an extra appetite for the morning's meal.

(Did you ever eat a bear's ham, by-the-bye?-Only let us kill this fellow, and if we don't save his bacon, 
ay, and digest it too, and you don't afterwards conscientiously declare that you "never tasted any thing half so delicious in all your born days,"-I say if you don't say all this, word for word, I most sincerely and charitably hope that you may one day perish of starvation.)

At length our guide points out his dwelling-placethe scene of the invaded domestic felicity; but strain your eyes as much as you like, you cannot distinguish it; an Irish cabin would be a palace to it.

We have reached his coffee-garden, and shall soon be upon the scene of action.

"Halloa! did you hear that growl? look out! (click! click!) who on earth would have supposed it ! Don't be in a hurry (or a 'flustration')," but before half of these words are uttered, head over heels tumbles the breakfast carrier, and very probably yourself, good reader, on the top of him, with merely the basket of fresh eggs brought out for breakfast between your two carcases.

Bruin having perpetrated a charge worthy of Waterloo, is toddling off as fast as a rather extensive morning's repast will allow him.

Having made sure of whatever remains of the wreck of eatables and drinkables by consuming them on the spot, a proceeding that in a great measure restores our philosophical equilibrium, we again sally forth bent upon ursicide.

We are not going to be knocked over a second time in so unceremonious a manner, so we pick our 
way through the underwood of the forest, as cautiously and stealthily as possible, almost on our hands and knees, our guns on full cock, and ready for another charge as soon as the enemy chooses.

Confound those innumerable blue wood pigeons! how they frighten-no, not frighten-how they make one start as they get on the wing every moment around us! but bruin has evidently cleared the jungle, for here we are out of the wood in a large open space, with shrubs scattered every here and there as regularly as if they had been planted; the turf under-foot is like velvet, and flowers that would grace the choicest rows in a hothouse, spring up wild and luxuriant in every direction !

Bearing a perfume more delicious than any cultivated plants I have ever met with, here they bloom, live their day or week, and die, without an eye to see their beauty, or a nose (except a pig's in an attempt to get at their roots) to appreciate the intense aroma of their scent.

Here let us sit down for a while, and regale ourselves with a diluted nip from our "pocket-pistol," whilst we send our followers forward to that mass of rocks ahead of us, and if we do not find the gentleman we are in search of at home, in some snug cavern thereabouts, I pledge myself to stand two dozen of "Moet's best" on our return to head-quarters.

$\mathrm{W}_{\mathrm{e}}$ are possibly engaged in the occupation of extracting innumerable diminutive harpoons from our 
legs, that we have collected in our way through the jungle, when a cry of "The bear!- the bear !"- from the reconnoitering party certifies that I was not far wrong in my surmises, and on arriving at the spot, we are directed to an opening in the rocks, formed by two masses of stone, having fallen against each other, apparently scarcely large enough to admit a cat, when on applying our eyes to the aperture, they encounter those of the quarry, glowing like two illuminated saucers at the extreme end of the den.

The first question that naturally suggests itself is how to get at the beast.

To shoot it "in its house," would be to lose it altogether. We must persuade it to egress-so draw your ramrod,-and whilst I probe it in some tender part, you stand by to shoot it as it comes out. Now, then, prong! prong! prong! - but it won't budge an inch-a sulky growl is all it deigns to vouchsafe us.-Ten to one it is a lady-bear with cubs !

A sudden inspiration seizes us, viz., to make a monster "black devil" (the component parts of which Satanic preparation are gunpowder and water, as every schoolboy knows, rolled into dabs between the finger and thumb, whereon the effect of fire is a great fizzing, a tremendous shower of sparks, and a most abominable stench), and to hurl it into the retreat of the bear; then seizing our guns, we await the dénouement.

Presently out pops the snout of a youthful member 
of the firm in a very asthmatical state; another, rather worse, soon follows; till the old dowager, finding her offspring getting smaller and smaller by degrees, condescends to look after them, and affords us a chance of avenging the indignity of the morning.

She no sooner perceives her intruders at such close quarters, than she is on her hind legs in an instant, dancing for all the world like a man in that execrable "pas seul" in "La Pastorale," and making straight up to the nearest person, which I will suppose is yourself, fortunate reader! she is soon within four or five feet of your gun's muzzle.

Now put in your "one, two," as Mr. Jackson would have said.

Bravo! right through the heart! - and a noble animal to boot; six feet from stem to stern.

Reader, that skin is yours. - The next time we go on a bear excursion together, let me have a chance. 


\section{CHAPTER IV.}

A MIDNIGHT MELÉE WITH THE UNCLEAN.

HAving (between us) avenged the demolition of the "hope of the family," and of the tortoise-shell comb, by the slaughter of the female victimiser, the least we can do in common charity is to adopt her orphan progeny. Consequently, tying a handkerchief round the neck of each of the three half-smothered juvenile bruins, we march them off in durance vile to enjoy a state of civilisation for the remainder of their ursine existence.

The sun beginning to get unpleasantly warm, we adjourn to the jungle habitation of our host, which the fair sex of the family (query, does a black woman constitute one of the fair sex?) during our absence have put into a "company-expecting" state for us, by festooning the walls with snow-white drapery, and laying out a respectable spread of milk, plantains, honey, and rice-cakes on the table (female, unsophisticated, little niggers!) 
But it is no easy matter to rest, even during midday, in the jungle, where there are so many incitements to sally forth and penetrate its depths, and assert and prove the dominion of Man and Manton over those who dwell therein.

To pass time, we have the defunct bear hauled into the verandah, and there skin the lady, making the delighted Native's sanctum very much resemble a slaughter-house both in appearance and odour, and a pretty mess of the business into the bargain.

This accomplished, and it is no slight labour (as you may easily discover, reader, if you only try your hand at skinning one of the three hundred and sixtyfive bears annually slaughtered at any barber's shop in the whole of London), we take a stroll to the adjacent "garden"-lucus à non lucendo-(as our senior captain " unde derivatur-ed" the assistant-surgeon of the regiment, who, not being over-brilliant in intellectual powers, luxuriated in the patronymic of Lucas), and assist the old "pater familias," who never ventures abroad beyond, in planting his garlic or betel-nut; and although, in the extremity of our officiousness and accommodating benevolence, we stick half the plants in the ground with their heads instead of their roots downwards, the native patriarch is so overpowered at our condescension, that he gives us an invitation on the spot to spend twelve months with him at the very least (to begin with), if it be only to murder some of the pigs that pay nightly visits to his

D 2 
habitation, and that will, ten to one, speedily undo all the work we have been attempting to accomplish in such a masterly manner.

Just won't we stop, my dear reader, now that we are here?-not twelve months, but twelve hours, and see if we cannot polish off some of the "unclean" (not meaning the "great unwashed," but speaking Israelitishly) that intrude their snouts here, eradicating every germ of vegetation in the garden, and of charity in the heart of its cultivator.

The sun is setting bright and brilliantly;-every fleecy cloud in the lately blue-but now gray-expanse above us is tinged with a deep crimson glow, decreasing in lustre as the sun sinks further down, and finally settling into a border as of burnished gold; till the Moon, getting jealous, pops its jolly round face above the horizon, and before we have time to say " What a glorious twilight!" the glare of day has melted into the hallowed stillness and subdued beauty of night-and now is the hour for action.

Without loss of time we proceed to pitch our bivouac (as some victim of poetic inspiration has immortalised it, but whether on a similar occasion or not we will not vouch),

By the moonlight, alone, At the grove at the end of the vale.

And as we are to spend the night, or the greater part of it here, we will take care, you may depend on it, 
provident reader! to be furnished with antidotes against any of the rheumatically-charged airs of the late hours.

Every step we proceed evinces in what numbers the swinish multitude amuse themselves " $\mu \in \sigma o v v k \tau \iota a \iota s$ $\pi \circ \theta$ ' $\omega$ paıs," the ground being literally turned up in all directions, as if it had been operated upon by one of our modern patent subsoil excruciators - in search of what, Heaven and the pigs only know! for often have I dug there for hours, expecting to find a nest of truffles, but might just as well have hoped, whilst I was about it, to have harpooned a Chubb's patent safe, full of old Roman denarii.

We are en route to a large open piece of ground some mile or so off, so spacious that at least two thousand porkers might go through Torrens's improved system of drill thereon, without treading on each other's heels or toes.

The still, stagnant pools (albeit looking clear in the moonlight), that we every now and then come upon, are on our close approach raised into a state of sudden and tempestuous commotion by the plunge of an alligator, whose calm imaginings on the bank our advent has merged into more egotistical and selfish considerations.

In other pools, we merely perceive the head of one of these monsters appearing above the surface, stargazing, or on the look-out for some poor paddy bird to alight on the water, in hopes of a quiet night's rest and pleasant dreams. 
These rascals ("guanas" they are called in Ceylon), are nothing in comparison in point of size to the Egyptian crocodile, but they are the greatest drawbacks to shooting with dogs, more particularly spaniels, for as sure as a dog enters a pool after a dead or wounded bird, so surely does he enter the ravenous maw of an alligator, who, with two inches of snout above the surface, seems all his life long to be actuated by the old nursery injunction of "Shut your eyes and open your mouth, and see what Heaven will send you," formerly accompanied to ourself, in pinafore days, with a huge lump of Spanish liquorice, or some other (then adored) abomination, until our confidence was destroyed by a huge dose of rhubarb one evening, when we expected tamarinds at the very least.

There is no use shooting these "guanas," as I have been more than once tempted to do, by sending a ball into their neck, for they only prove so much nourishment to the other part of their family, and are soon gobbled down by a bereaved and hungry circle of acquaintance.

They will generally attack every thing, man and beast, in their own proper element, water; but meeting a human being on land, they invariably "cut their bamboos," and take to the nearest pool.

At last, we emerge into an open plain covered with lemon grass about a foot in height, and bounded all round by the jungle; when following the directions of our "indigenous" guide, we plant ourselves at an 
opening through which the herd are expected to make their appearance, stationed at such a distance as to be able to keep up a cross fire without any great chance of immolating one another; and then squatting on the grass, or perching ourselves on any rock that may accommodatingly be in our neighbourhood, we light a cheroot, the more effectually to keep our mouths shut, and, like two Jobs in shooting jackets, await patiently the first squeak or grunt of the invaders.

Our guns are loaded with ball; in addition to which we carry a crease a-piece, which we have borrowed from some of our Malays, with whom it is a favourite weapon, and almost the only one in use, in their own private quarrels or piratical crusades.

In the Ceylon Rifles, nine men out of ten, if engaged in active service, carry their creases with them, and during the Cingalese rebellion where the regiment was employed, a hundred of the enemy were found to have been "creased" to each one that was shot; and a singularly unpleasant sensation it must produce;-being bad enough in all conscience to be transfixed (at least so we should imagine) with a plain straightforward bayonet, instead of one of those zigzag, corkscrew-shaped things.

Back to our " cochons."

In any other place, perhaps, our patience might get up a slight demonstration of mutiny and rebellion by way of an interlude, but here we feel we could wait all night, even though nothing turned up. 
Our cheroots are excellent-our "pocket-pistol" not likely to be exhausted-and our train of thought the most amiable possibly to be imagined.

Who could profane "the solemn silence of that hour," by the explosion of villanous saltpetre?Who, in this "stillness that leaves room for the full soul to open all itself," could send to an untimely grave even the minutest of Heaven's

By Jove! was that a squeak? Yes!-Hark! another, and another, and another!-here they come! -hip! hip!-(not loud but deep) hurrah !

Ay, borne on the wings of one of those airy gusts that fitfully eddy down the miniature valleys in the jungle, comes the first quaint squeak of piggy on his pilgrimage !-

Louder and louder swells the chorus!-Grunts, such only as can issue from porkers starving, or deeply insulted, become fearfully distinct; until, at a swing trot, about two hundred fine savage swinehog, sow, and progeny promiscuously blended-burst through the opening where we have been expecting them on to the plain, and appear at one coup d'cil before us.

It is as light as day; and the animals in the moonlight lock as white as if they had a prognostication of the fate that awaited them.

Now they slacken their speed, and at once set about the business of the night-viz., grubbing.-

We crawl on in the rear, about twenty yards astern; then dropping quietly on one knee, pour in 
our four barrels; seizing the spare guns from our servants, we administer a second dose, our followers reloading the discharged weapons in the interim.

The pigs are evidently staggered.-It is too much for their limited intellect to comprehend, and with the exception of three dead, and two lying on their backs, squaring away at the little of existence left (pardon the cribbage, oh Boz!), the herd "form square," getting as close to each other as possible, and turning a front towards us as if determined to make a rush; but before they come to any fixed resolution on this point, they get a third volley, and then - " every pig for himself" - away they toddle as fast as their trotters will carry them.

Our wisest plan would have been to have provided ourselves with two ponies, in which case we could have followed them up until we had exterminated the entire herd; but having no such appliances at hand, our only resource is to rattle after them on foot as quickly as we are able; of course they soon distance us, but presently arriving at a convenient place for another attempt at supper, they pull up and again set to work.

Again we pepper away at them; and one or two, hit hard, make a rush at us; this we avoid by quickly making an echellon movement to the right or left, for it is no joke to come in contact with one of these wild fellows.

Their plan of attack is to rush at the legs of their 
adversary, and as they knock him over, to throw up their heads at the same moment with fearful force, inflicting a contused wound that would probably disable the receiver for life : to say nothing of the gash they are capable of inflicting with their tusks, which are tremendously long and sharp.

Should we be rendered insensible by one, the others would incontinently devour us, so it is not altogether such child's play as may appear to the reader on perusal.

Tired at length, and out of breath, we give up the chase; as for carrying the dead pigs away with us, we would if we could, but they are too numerouswe have killed upwards of a dozen; so picking out the plumpest, we sling him on a pole, soon cut from the nearest bamboo tree, and placing either end of it on two of our followers' shoulders, we trudge home to quarters, calling in our way to pick up the bear captives of the morning, and arrive in time to "turn in" just as our little bantam greets the opening day with his first " cock-a-doodle-doo !"- - 


\section{CHAPTER V.}

\section{AN "ESSAY" ON ELK.}

Turning out somewhat late in the day after our midnight excursion, and discussing a light déjeuner, consisting of a pine-apple and a bumper of diluted claret (the former article being wrenched out of the nearest hedge, and the latter subjected to an external application of saltpetre, which does duty in the jungle for the more extravagant luxury of ice), the next "divertissement" in out-station life is a demonstration of valour in the shape of an undress parade, at which we rout an imaginary unoffending enemy by twenty rounds of blank cartridge to each man, frightening the adjacent niggers and their poultry-yards out of all the little wits they possess between them, and, as in duty bound, doing "all our little possible" in keeping up the glorious taxes of Old England by a huge waste of gunpowder.

But however bloodless all this "pomp and circumstance of glorious war" is to the invisible foe, it is 
not so to us; there is not a blade of grass on the whole parade ground that is not the local habitation of a leech; -not content with the grass, they patronise the trees, and drop down into one's neck and hair without number, and so small are they, that they insinuate themselves through the button-holes in one's dress, and the slightest puncture in the world makes the victim aware when each young blood-sucker has set to work.

As to detaching them at the time, that, not constituting one of the new drill manœurres, is totally impracticable; and often have I, on reaching the bungalow, after smarting for an hour or two under their tender mercies, rushed into my bedroom and removed from one hundred and fifty to two hundred of the bloated rascals from my neck, arms, and legs, which of course were streaming with blood.

However, as the district surgeon consoled me with the information that they tended in a great measure to regulate the corporeal thermometer, I made up my mind, after a time, to bear all their blood-thirstiness patiently ;-although when some fellow, presuming on my forbearance, gave a nip that made me start again, I own it was not without "malice prepense" that I inflicted such a kick on the particular spot of my leg on which I supposed him to be located, with the heel of the other foot, as almost sent me on my knees in the midst of some very complicated light infantry tactics. 
But during all this interesting interlude, we will suppose yourself, my dear reader, to be charitable enough to be cleaning our guns, and cutting chops out of the murdered pig that hangs in the verandah, whereon we may enjoy a late dinner, and secure ourselves the moral certainty of such a night-mare as will cause us no want of inclination to jump out of bed next morning with the first peep of daylight, and to see if we cannot vary the day's " carte" by a venison dinner, although you must excuse its being unattended by the customary confectionery satellites; had the interior economy of the "genus cervus" been left to our simple construction, I dare say we certainly should, by a special dispensation of our own, have endowed each animal with a receptacle for currant jelly among some of its other numberless, and-to all culinary intents-useless, interior appendages.

There is no such variety among any one tribe of animals in the whole brute creation, that I am aware of, as there exists among the deer of Ceylon.

First and foremost, we have the noble and beautiful elk, standing fourteen hands in height,-its antlers branching some six feet above its front,-its dark full eye and bright silky coat, - the exceeding elegance of its long and taper understandings, the fine drawn tenuity of which you would imagine that the weight of its carcase in its bounding leaps from rock to rock would snap like a reed!

To see one of these noble creatures in its own 
peculiarly wild and almost inaccessible lair, is one of the finest sights in nature; and it is singular that an animal endowed with such strength and fleetness, living in such a state of savage hardihood as the elk does, and defending itself, when attacked, with such determined courage and resolution, should be the last animal in the jungle to act on the offensive, and the first to take to flight on the approach of man.

Taking it for granted that our first day's excursion over the mountain has not entirely passed away from the reader's recollection, we will once more make it the scene of action, and if between us both we do not bring down a noble elk (although we may go a hundred times over the mountain and not see one) to end its mortal career in the inglorious precincts of a stew-pan, there will be numberless wild minor commodities to fill our game-bag, and to amply repayif not our disappointment-at least our toil.

But we will not be disappointed this time, at all events, for, although it only once fell to my good fortune to bring down an elk, I will proceed to shoot him over again in the companionship of the reader, for his special (the reader's, not the elk's) gratification.

Summer or winter, there is little difference in the hour that it is necessary for one to sally out in the morning to enjoy the best part of the day, being that one immediately preceding sunrise ; although it is by no means an uncommon occurrence to be awakened 
considerably earlier by the sound of an elephant pulling and tugging away at one of the verandah posts, the dénouement to which amusement there is every reason to believe that five minutes more industry will most satisfactorily (on the animal's part) accomplish.

This may be more exciting than agreeable; for, if one remains in bed, the chances are twenty to one that the whole roof will incontinently come down upon him; and should he summon courage to go out in the dark in hopes of a random shot, the chances are just as great that he takes the place of the beforementioned persecuted verandah-post, or perpetrates a nocturnal elopement to the jungle in an elephantine embrace.

There is a peculiar wildness of fragrance about the jungle at the first break of day; - the heavy dew of the night standing in large drops on every atom of foliage seems to distil the very essence of the herbage on which it has alighted, and as the sun evaporates the dew, the fragrance it has absorbed appears to be let loose on the atmosphere; the lemon-grass is particularly oppressive in this way, being more like essence of verbena than any thing else I can just now remember.

The route that we take to-day differs from our previous one up the same mountain, for, being in search of elk, we must explore the more precipitous and craggy localities; therefore, diverging at once 
from the ghost of a path we have been following, we are immediately afterwards crawling and scrambling as best we can, up sharp and almost perpendicular rocks,-our gun slung over our shoulder by a leathern strap, - whilst we employ both hands in holding on at every diminutive tuft of verdure that pops its unsuspecting little existence out of the fissures of the precipice; till, reaching an inviting-looking apex, we probably find we have to slide down a declivity equal in length to the one we have surmounted, with another and more difficult ascent on the opposite side.

These places swarm with hares (which, by-the-by, are much more like rabbits), and innumerable are the jungle fowl that get up on all sides of us ; these birds resemble in a great degree our domestic fowls, excepting that they possess a remarkably wild game-y flavour, and their plumage is considerably handsomer ; that of the jungle cock is magnificent.

I used to constitute these birds the chief article of my larder, and the way I always managed to secure a fowl-curry when I wanted it, was in this wise-

("Foul" play, I dare say you will call it, reader!)

I had a perfect trump of a little bantam-cock that I used to tether about ten yards from the skirt of the jungle, in the dusk of the evening, and ensconcing myself in the boughs of some sturdy tree about twenty yards distant, I waited patiently the result.

The decoy would presently set up a most deter- 
mined hulla-baloo, at which the hens, overcoming their maiden modesty, would sally forth to offer their services;-whilst the cocks, than whom a more pugnacious race never existed, had only to hear the crowing of one of their brethren, than they would, with brotherly love, immediately come to a pitched battle with him.

Of this part of the fun, however, I disappointed them, by taking the fighting part of the business on myself; for, as soon as they were well clear of the jungle, I sent a load of shot at them, and rarely ever missed so inviting an object.

In this manner I have shot upwards of twenty jungle-fowl of an evening, or by moonlight; and I really believe the decoy at last understood and enjoyed the sport as much as myself, except when he came in now and then for a stray pellet of shot in a tender part.

To describe every minutiæ of the perilous ascents and descents over the mountain after elk, however exciting they may be in reality, when we are one moment swinging our bodies over ghastly-looking bottomless pits-scraping the bark off our shins - and carrying away all the "behind" of our "un-hintat'em-ables" in undertaking a gradual descent on the broad-guage principle, by bringing the widest portion of our entity to bear on the greatest possible surface of rock, is a very tame piece of work when merely transcribed on paper to be read and "poohed" and "pshaw-ed" by some jolly fat old gentleman in 
a morocco arm-chair, as devoid of sympathy (the occupant, not the chair) and compassion for our perils, as he is full of contempt for our fool-hardiness, or of delight at the prospect of our broken collar-bone.

However, it happened one fine day, after I had spent about half-a-dozen hours in scrambling over the hardest rocks that I ever came in contact with in my life, that on reaching the summit of my ambition, I was met face to face by the most magnificent elk I had ever encountered, standing on the same ridge of rock as myself-so sudden and so electrifying was his noble appearance, that we stood gazing in mute astonishment at one another for a very considerable time; how long, it is impossible to say.

Every idea of having a gun in my possession, and of the "mission" on which I was engaged, had oozed out of my composition, and which was the most astonished of the two is not a matter that can ever be very satisfactorily proved, but the elk was the first to regain his reasoning faculties.

Throwing up his head into the air, he gave a half-neigh, hálf-scream, like that of a frightened horse, which also had a revivifying effect on myself in making me unship the double-barrelled rifle, still slung behind me, and take advantage of the instant left to commence the fight.

In a second he had made a bound to an adjoining ledge of the precipice, to gain which he must at the very least, have cleared ten yards of space, when without taking aim, or even having time to bring the 
gun to the shoulder I pulled the trigger, determined not to let him off without a random shot, and in this instance it was as efficacious as a more deliberate one would have been, for the ball striking him in the back bone, I could see his spring was broken before he reached the ridge he sprang for. His fore legs alone reached the rock, and his hind legs would even then have found a leverage below to have carried him on, had not his hind quarters become perfectly powerless.

Clinging on by his two fore hoofs, he struggled for upwards of a minute with most desperate energy, till, slowly and by degrees, the little hold he had got gradually became less and less, until he had receded to the very edge of the rock, there hanging on for a moment in agony, he lifted up his head as if in one imploring look for help from heaven, and nature relinquishing the struggle, the next moment saw him bounding from crag to crag into the ravine below, his whole frame appearing at each bound to crash into a pulp, or a million fragments!

But he was gone! irredeemably lost to me and my heirs for ever! What would not I have given for his antlers, and for his skin!

If ever I felt inclined to the melting mood (except the perspiring one) it was at that identical moment. To have squatted down then and there, and, digging my knuckles into the corner of my eyes, to have given way from sheer vexation and rage to the in- 
fluence that is said to possess such magic effect on the overwrought feelings of the softer sex, on far more trivial occasions, would indeed have been a luxury; but I did not do so-at least, if I remember rightly I did something much more irreligious, or if I did not, Echo did it for me, and another more distant Echo, like a kind-hearted, sympathising fellow, immediately manifested that he entirely coincided with my sentiments, and the mode of expressing them.

But there is no peace for the wicked!-I had scarcely discovered the loss of the elk than I had a very strong perception of the loss of myself; not having the remotest idea of the way I had ascended, nor of north, south, east, or west ; in short, about as small a notion at that particular moment of the cardinal points as I had of the cardinal virtues.

Always accommodating myself to existing circumstances, I at once commenced feeling for the softest rock on which I might pass the night, when the recollection of what a "feather-bed in such a predicament the elk's carcase would have formed, made my loss doubly mortifying ; in the next place, philosophically lighting a cigar, the clouds of discontent began gradually to disperse (much against my own inclination, however), until getting as fleecy as the fumes that befriended them, they took advantage of an unguarded moment to amalgamate, and to vanish (like all ghosts do), in a wreath of blue smoke.

Finding that three hours of daylight yet remained, 
I thought the best plan would be to gain the summit of the mountain, and then return on the next morning by the first day's route; the first part of the work was at last accomplished, and having dedicated an hour to cutting all the grass I could find on the place to do duty for a mattrass on the top of the rock, I left the full moon standing sentry directly above me, and was soon once more amid the scenes of childhood, surrounded by all I loved and left in Fatherland!

The following morning's work was easy.-At ten A.M. I had reached the bungalow at the base, loaded with a plentiful supply of feathered game, and never shall I forget the delight I experienced, when in strolling over the space before what was once a door, now covered with jessamine and briars promiscuously, I pounced upon half-a-dozen over-grown beds of magnificent ripe strawberries !

The fact of the matter was, that the bungalow in question had been built as a country residence some years before by a gallant commandant of the district, who, taking advantage of the mildness of the climate, had laid out the grounds in as English a fashion as was possible; but contending in vain against his forest neighbours, he at last relinquished gardens, house, and all, in despair.

However, when the strawberries became invisible from being concealed by a complete covering of 
brambles and underwood, there was a chance of their escaping the ravenous maw of a pig, or the coveting propensities of a baboon; and thus, after many a long year's waste of sweetness, they once more re. turned, like blushing prodigals, to the uses ordained to them at their first début into existence.

(But on my hands and knees, reader, let me veil myself from your sight for an hour.) 


\section{CHAPTER VI.}

A FORTNIGHT'S EXCURSION AMONG THE ELEPHANTS.

AfTer having allowed yourself, like a good, docile, and accommodating reader as you are, to be so incontinently dragged, on our last excursion together after elk, over a wilderness of hard-hearted crags and yawning chasms, to the serious abrasion of your shins and the deterioration of your nether habiliments, you shall now have your reward by an introduction to the monarch of the forest-the leviathan of creation-the Elephant;-and, in its slaughter, to the "crack sport of the Ceylon jungle."

There is something indescribably soul-stirring and exhilarating, however much we may be hacknied in the sport, when we see one of the kings of the jungle (which the elephant decidedly is, and the lion a mere pitiful usurper) sink dead upon the ground at the feet of such a speck on nature's face as man in compari- 
son to the monster against whom, single-handed, he enters the arena.

It is not the mere ordinary pleasure that one experiences in sport generally, such as running into a fox after a forty minutes' chase-(and there are few excitements more enlivening or heart-thrilling than that), or the self-satisfied complacency that one feels on the eve of a first of September, when the spacious pockets are relieved of some thirty brace of birds; but it must be the consciousness of the power of man over every beast of the field, and the pride of wielding it, that causes one to feel such intense gratification when an elephant is brought down in the midst of its own native wilds !

To such perfection has elephant shooting been carried in Ceylon, that I fear every reader who had never visited those shores would consider the "Jaunts" far too "Munchausenish" if I related every anecdote connected with the slaughter of the elephant that has fallen under my own immediate observation - in short, it is much better to keep all matters of wonderment to oneself rather than lose irretrievably a reputation for truth by being the unlucky possessor of the knowledge of some extraordinary feat that could only produce incredulity in ninety and nine readers out of every hundred; in illustration of which I will relate an anecdote that actually occurred at a well-known club-house in London not very many years ago, where foreign sports becoming the topic of conversation 
- and amongst the rest elephant-shooting - an officer, just returned from Ceylon, ventured to assert that, to his own individual knowledge, a brother officer had slain with his own gun alone fourteen hundred elephants!

This was too much to be endured, and the whole room, taking it as a joke, burst into a roar of laughter, which increased in proportion with the vehemence of the unhappy sponsor of the assertion, who forthwith offered to bind himself by any quantity and quality of affidavits the company might choose to impose, as to the truth of what he adduced.

Whilst in the midst of his discomfiture and indignation at his word being doubted, General C-_- entered the room, who had also lately returned from the same place (and to whom the fact was perfectly well known, and to whom it had been well authenticated).

"And now," exclaimed the discredited one in a "blaze of triumph," "if you do not believe me, here is General C_-, who will vouch for the truth of the fact."

The question was accordingly put to the General, who was about forthwith to answer in the affirmative, when a second burst of laughter at such an improbable and Major Longbow-ish event indicated to him the real state of things, and, with the greatest composure and nonchalance in the world, he at once not only avowed himself perfectly ignorant of the marvellous occurrence, but further expressed his entire disbelief in it! 
Poor —, at being so unexpectedly left in the lurch, to stand the brunt and reputation of being gifted with certain inventive faculties (vulgarly called lying), endeavoured to mend matters by seizing his hat; rushing straightway to his chambers, and then and there concocting and transmitting a hostile billet-doux to the General for not supporting him in what he knew to be a fact.

The answer to this pugnacious missive followed immediately in the appearance of the General's goodhumoured physiognomy, and on being upbraided for his treachery in thus "backing his friend," he replied,

"Pooh, pooh! my dear fellow, don't be so savage! I am well aware that what you said was perfectly true, but seeing that every body in the room was fully persuaded that you were telling a falsehood, I had no ambition to appear in the same light!"

Captain — never showed his face again at that club during his furlough in England, but his story was perfectly a matter of fact, and the gentleman who had shot that amazing quantity of elephants was the commandant of that particular district of the jungle in which I was myself located, one of the most excellent men that ever lived, whose exceedingly polished and unassuming manners would rather indicate him the destroyer of fourteen hundred hearts than the same number of elephants!

If you ever had, Reader, the good fortune to make the acquaintance of poor Tom Rogers, Major in 
her majesty's Ceylon Rifles, you know the man alluded to.

These pages, I regret, can never reach the eye that never missed its aim, for after having escaped (how miraculously! Heaven alone knows) for twelve years, every danger of the jungle, in one continued war against the elephant tribe, he was, not long ago, struck dead by lightning when engaged in his favourite pursuit! (A glorious day that, in the elephantine calendar!) The fate of one whom the united brute creation could not touch, the flash of the mountainstorm, as if jealous of his supremacy, at last accomplisheả! A small black spot on his foot, and the lost lustre of that soft blue eye as he sank upon the mountain, alone indicated the finale to the existence of the most extraordinary elephant slayer that ever lived on the earth!

The fate of the unfortunate brute that was shot some years since at Exeter 'Change, when half an army was drawn up to pepper away at its carcase for hours, is certainly sufficient to make one sceptical on the point that one little ounce ball, properly administered, will as effectually demolish an elephant as it will a bluebottle, but so it is; - the animal's skull in some particular spots is not much thicker, if at all, than that of a man, and the brain is quite as accessible, (much more so than some men's) and should any of the tribe hereafter take it into their heads to take leave of their senses, I hereby most 
disinterestedly and charitably offer my services to the whole imported fraternity from the Drury Lane Jenny Lind downwards, to put them out of their misery with a single shot, or to keep them in rum and rice for the remainder of their natural lives.

To make certain of accomplishing this feat only requires a certain degree of practice and a thorough knowledge of the internal formation of the animal's head, which must be acquired by splitting one transversely, and thoroughly anatomising the numerous honeycombs or square receptacles of which it is composed.

But now-Hey for the Jungle!

Although the information of the vicinity of a herd of elephants to one's bungalow (particularly if there happens to be a tusker among them, the possession of whose "ivories" will compensate a man for his risk and trouble by furnishing him with the means of procuring two excellent fowling-piecesivory fetching, I believe, five shillings a pound), induces one to sally forth at all times to enter the lists single-handed against the invaders, still to enjoy the sport of elephant shooting in perfection, it is necessary to form a party of four or five people-(quite a sufficient number for comfort and safety) - and these jungle re-unions are principally concocted at headquarters, from which place intimation is sent to the out-station nearest to which the anticipated campaign is to be carried on-constituting no small treat to the 
lonely dweller thereat, as he then comes in for a share of all the good things furnished from a more civilised part of the globe than that in which he himself vegetates.

A party having been made up for a fortnight's shooting, in the first place about twenty coolies are collected together, and are forthwith laden with every imaginable article, edible and potable, that can be had for love or money-rounds of beef, hermetically sealed soups, hams, concentrated vegetables, buffalo humps, biscuits, and bread ad infinitum, added to each fellow's particular preference in the cellar department, constituting the commissariat.

The individual fancies of this latter delectability are in no slight degree varied-par exemple:-A jolly John Bull of the party fancies he may again relish in the jungle the potent flavour of a full bodied port - another person prefers a six dozen case of Château Margaux - whilst a third, with a longer stretch of imagination and purse, declares nothing will go down with him but Moet's sparkling Champagne, which, occasionally diluted with soda-water as a refresher after the toil and slaughter of the day, he has a very strong idea cannot easily be surpassed.

On the subject of pale ale every body agrees, ditto on brandy pawnee and cheroots, so that when we commence unpacking the articles at their final destination, there really is every ostensible inducement to forego the pomps and vanities of this wicked world, at least until we are starved back to them again. 
The dweller at the out-station, from his situation, is always provided for by the others, and to do him justice, he certainly makes the most of his time in laying in a stock to last (or at least the remembrance of it) till he is again summoned to the well-supplied board of another elephant party, and what is more delectable than all this, is the revived companionship of our old friends and associates, whose vivid recitals of what is going on "in the world" makes one emulous of again shuffling off the coil of jungle-life -of exchanging the companionship of monkeys for that of men-the wilderness for the world-and of henceforth pursuing a Beauty instead of a Beast.

Although there are very many localities in different parts of Ceylon well adapted for a crusade against the elephants, the preference is usually given to a place called Neilgella, on the eastern part of the island, but nevertheless, some distance inland.

Neilgella is an extensive, undulating plain of many miles in circumference, bounded on all sides by mountains covered to their summit with verdure, whilst the ground itself is ornamented at regular distances by large clusters of forest trees, which in their regularity so perfectly resemble those of an English domain, that the place has long since been dignified by the soubriquet of "the Park."

At some seasons of the year the elephants (in former times) used literally to swarm here, whilst the myriads of red deer with which it abounds make it the scene of the ne plus ultra of the deerstalker's enjoyment. 
The park was first discovered by the above-named officer, Major R., during one of his many rambles after elephants, and so supernaturally wild and beautiful was its appearance as it suddenly burst upon him after an uninteresting scramble through a monotonous description of jungle, that, to use his own words, he remained some minutes as if spell-bound, nor would he have been more entranced had he discovered a colony of those little demi-immortals, that came in and went out with the "Arabian Nights," in comfortable possession of the scene.

It was many years after its first discovery that I had an opportunity of visiting the place, and any thing more beautiful I certainly never beheld; its extent was incomprehensible to the eye, and one might wander on-on-on-from morn till eve, still there was the same view before him, with the tall blue mountains in the distance; but if the prospect alone produced such an agreeable surprise to the discoverer, judge of his amazement and delight, when, on penetrating further into it, he found it actually dotted in all directions by innumerable herds of elephants ; some reclining under the shade of the forest trees, whilst others were laving their huge carcases in a broad river that ran through the place.

"Here will I build unto myself an habitation," was his first ejaculation; and on that spot does the house stand to this very hour (that is to say, if the elephants have not wreaked their revenge on it since 
my departure), free and open for every person living in the island to make use of as his abode, as long as it is dedicated to the uses intended it by its proprietor, viz., a shelter for the "enemy of the elephant;" so to this primitive abode, my dear reader, I will now conduct you, and promise you that you shall return from it both a wiser and a browner man.

The head-quarter party having picked us up at our out-station, some thirty or forty miles from the park, our route for the rest of the journey lies through the mountains, and we have no slight trouble to reach our destination by the following afternoon, just in time to arrange matters comfortably, both of a domestic and of a warlike nature, before darkness covers the scene.

Threading our way through the lemon-grass, and starting herd upon herd of wild deer in every direction as we advance, we at last perceive in the distance the white-washed walls of a bungalow, about a mile a-head of us, welcome enough to us at present, although looking wretchedly cheerless and uninviting in itself.

On approaching nearer, unmistake-able symptoms of the continual visits it is in the habit of receiving from buffaloes and elephants do not impart to it a more hospitable appearance, nor does the interior tout ensemble promise much in the way of ease and luxury, as we desolately gaze on the rude, solitary table, whose legs are formed from the uncarpentered 
branches of a bamboo-the three "condemned hospital"-looking stretchers, made of the same material, and held together by a net-work of coarse coir ropeand the two crazy chairs with one seat between them.

A couple of hours industriously spent, however, furnish it with a very materially improved appearance, the nakedness of the stretchers being hidden by the mattrasses that we have brought with us, and these drawn close to the table on either side make a luxurious imitation of ottomans, whilst a gun-case, laid across the two seatless chairs, is pressed into doing the extra duty of a form or a side-table.

But whilst we are driving our wits to the very furthest verge of their inventive extension, a new visitor makes his appearance amongst us, a personage of no little consequence to us in our anticipated excursions.

$\mathrm{He}$ is the Genius of the place, the only human dweller in all that vast and glorious wilderness, and well does his appearance harmonise with the romantic character of the scene. .

His long hair, perfectly white from age, is tied up in a knot at the back of his head; whilst, in front, a snowy beard undulates half way down his breast. His only covering is a white linen girdle round the loins, and his only defence against all the wild beasts that surround him, is the peeled willow wand that he carries in his hand.

In that old jungle-patriarch, reader, you see our "Elephant-finder." 
$\mathrm{He}$ is personally acquainted with every herd of elephants encamped within a dozen of miles of us at that moment.

They, unsuspecting innocents, little dream of the treacherous part he acts towards them, or that slender willow wand would not so easily effect a lane through the centre of a herd for him to pass on his course.

But he has no fear, never having been harmed or attacked by an elephant in his life, although he has lived all his days in the very centre of their haunts; and whilst he enjoys the sport of seeing them shot, I doubt not but he is not a little astonished and amused at all the pomp and circumstance attending their destruction at the hands of the "white man."

Formerly, an elephant-finder's services might have been dispensed with, but so numerous and frequent have been the invading parties on this territory, engaged in that animal's destruction, that they have in a great measure been scared away from the plain to the denser parts of the jungle.

We are forthwith put in possession of a statistical account of the enemy, the exact spot each herd at that moment is in possession of, the length of time they have been there, and the advantages of the locality for our taking up a good position.

If there is a tusker among any of the numerous herds in the vicinity, the old man is entitled to a considerable addition of good things from the lucky fellow who brings him down. There being only about one 
elephant in every two thousand in Ceylon that possesses tusks, they are considered a great rarity ; and such a distinguishing mark of beauty are they regarded by the animals themselves, that on the approach of danger, the "tusker" is invariably surrounded by the remainder of the herd, and, thus forming literally a body-guard, they protect him until the danger is over, or until each elephant has been shot down dead as he stood.

Five o'clock the following morning is the hour fixed upon for commencing hostilities, and the old native, having been constrained to drink our healths in a bumper of brandy-pawnee (a proceeding, though hostile to his creed, apparently not by any means so to his personal feelings) is allowed to depart to acquire fresh information of recent arrivals, whilst for our own part, having put our house in order, we turn our attention to assisting the cook in getting ready the "feed" for the evening; nor on such an occasion did I ever know the old adage to hold good, of "too many cooks spoiling the broth," as every body has a great idea of culinary art in the jungle, and much latent gastronomic talent is therein developed; besides, as every-one concocts a hash of his own, he is obliged to praise and eat it in selfdefence, so the whole party is pretty sure of being satisfactorily accommodated.

If one could but virtuously and determinedly resolve on going to sleep as soon as dinner was over and 
digested (that is to say, about nine, P.M.), how clear would be the head and steady the hand the next morning at five, A.M.; but whether it is the everlasting rule of contrariety that regulates human nature generally, or the idea that we may possibly not survive to pass another evening in the same agreeable manner, that invariably makes the claret more fruity, the beer more malty, the cognac more seductive, and the cheroots more aromatic, is a question I would at present rather not undertake to penetrate into the depths of; but certain it is, that in nine cases out of ten the slightest ghost of a headache, and the pop of a soda-water cork at our neighbour's bed-side the next morning, brings remembrance and repentance at the same moment into our hearts.

This being our first excursion, however, the excitement consequent thereon leaves little room after a few minutes for other reflections; we are about to encounter a wilderness of monsters, the slightest contact with the weakest of whom would leave difficult work for mortal experience to remedy; and after all, there is a mighty small degree of $\kappa v \delta o s$ attached to being crunched like a beetle under the feet, or within the proboscis of an offended elephant; such were the thoughts that, no doubt, preponderated in the minds of the party generally as we sallied forth for the first time from the bungalow into the plain.

Leading the van, marched the old Elephant-finder, 
having most emphatically enjoined the strictest silence on our part wherever we followed him ; then came the firing party, ourselves, walking in Indian file; and lastly, our attendants, carrying one or two spare guns each, brought up the rear.

Having gone about half a mile from the house, the guide came to a dead halt, and plucking a hanơful of grass, threw it into the air to discover in which direction the wind blew, for it is necessary to approach the animals against the wind, their power of scent being so strong that they would be aware of our presence several hundred yards off, and keep at a most respectful distance for the remainder of the day.

Finding we are in the right direction as far as this is concerned, we are given to understand that we are within a quarter of a mile of the nearest herd, consisting of about thirty animals.

We then divide into parties of two, accompanied still by our spare gun carriers - the elephant-finder taking under his especial patronage the most inexperienced duo of the party; in this manner we are enabled to attack the enemy both in front and flank; and all the necessary instructions having been imparted, we proceed forward as noiselessly as possible; you and myself, reader, forming a party of ourselves, and patronised in the present instance by the guide, who almost frightens us out of our wits at the savage contortions he makes at us when we unhappily chance to snap a withered twig in our progress, as we wind 
our way like two boa-constrictors through the underwood, in any thing but a delectable state either of mind or body.

Look sharp, now !- Up goes the old man's hand in the air, and at the signal down we drop as mute and motionless as a pair of oysters, expecting the next moment to have the whole of the herd on the top of us.

Leaving us in this position for a minute or two (it seems an hour) the finder crawls forwards on hands and feet, every now and then peering above the branches to get a view of the quarry.

A slight beckon with his hand, without a turn of his head, releases us from our uncomfortable position, and again we are creeping slowly towards him.

He points forward, whispering at the same moment "Ellia!" (the elephants!)

We are at the extremity of a patch of jungle, and the animals are located in an open spot about twenty yards ahead, but still we are unable to perceive them, so silent are they, and so exactly do their bodies resemble in their hue the natural appearance of the jungle itself.

A sudden report of a gun on our right alters the scene entirely. It is as if a stone was hurled into a wasp's nest.

In another second we burst into the open space, and find ourselves in the centre of about forty wild elephants, all running here and there, wheeling and 
counter-wheeling, in an agony of apprehension and alarm ; each expecting his neighbour to lead the way off, and each having apparently lost every tittle of instinct; and now is the exciting moment-the moment to try what a man's nerve is made of, as well as to test his coolness and presence of mind.

It is useless to fire away right and left in the hopes of a random shot bringing an elephant down. Your life depends on your loaded barrel ; and ensconcing yourself near a corner, you wait patiently until an animal marks you out for a charge and comes directly at you, or, in passing in front of you, presents an opportunity that you cannot forbear taking advantage of.

Still, if it is possible, one should always have a barrel loaded, but if all happen to be discharged, keep a look-out for a neighbouring tree or rock, around which you can dodge the animal, for if you can do this, you have a decided advantage over him.

When the elephants are thus attacked in front and flank by experienced hands at the work, they are dropping thick and fast. Escape in the rear is prevented by the nature of the ground, and as they wheel round in confusion on receiving the fire of one party, they receive that of the other.

No person ever thinks of firing at an elephant at a greater distance than a dozen paces, so if one has the faculty of remaining cool and collected, it is not very easy to miss the vital spots in the head, which 
are the hollow part in the centre of the forehead, about as large as a dessert plate, and two similar places, of a corresponding size, just immediately before the ears; a bullet penetrating either of these parts must find its way to the brain.

The excitement that the novice experiences on bringing down his opponent apparently with so much ense, (albeit he has previously had a dozen shots without any visible results following), is apt to make him headstrong and careless, and numberless and providential have been the escapes caused by too great self-confidence and foolhardiness in this respect.

I well remember the first shot that I was fortunate enough to obtain at an elephant, and its consequences. The brute was within six yards of me when I sent a ball at his temple-not then knowing the exact spot that was mortal, I happened to hit him about an inch ton high, and divided an artery, on which a stream of blood spouted out like a jet of water from a fireengine, giving me as complete a drenching as if I had been soused in the Red Sea, completely blinding me for some minutes, and leaving me in a vastly pleasant predicament to continue the morning's work.

A fearful crash of branches on all sides, as I retreated into the jungle to rinse the blood out of my face and clothes indicated the final rush and escape of the remainder of the herd. 
Driven at last to desperation by stray shots from the tyros of the party, one prevailing sentiment seemed to animate the wounded wretches, and sauve qui peut became the order of the day, leaving us in possession of the slain, which amounted to about eight or ten elephants.

Having satisfactorily arrived at the conclusion as to who was the slayer of each particular animal-a matter not very easily accomplished, where every one is so ansious for "the honour of the thirg" - (a point, however, generally conceded by the veteran to the more inexperienced), we proceed to congratulate each other on the event, whilst our servants are engaged in amputating the extremities of the animals' tails (the trophy we preserve of our victims), which, being covered with long black bristles, have been made useful and ornamental by some enterprising elephant shot, by being highly polished, and turned into bracelets-six bristles kept apart at regular distances by small bars of gold, making a very unique and exceedingly pretty ornament.

But whilst we are quietly contemplating the aforesaid process of amputation, one of the fallen monsters, whose turn it has come to be operated upon, suddenly springs up into life, having been merely stunned, and makes us look out for ourselves; a general volley is showered at his head, and he gets off or falls for the last time, as his stars have ordained it.

After undergoing a scraping, added to an ablution in an adjacent muddy pool, during which time the 
remainder of the party have secured their trophies, and refreshed themselves (with, I am afraid, something stronger than tea-water, even at that early hour), away we proceed after the next nearest herd.

In some cases, perhaps, we attempt to pursue the fugitives, but this is, in general, lost labour, for, as the "burnt child dreads the fire" (a proverb, a Milesian brother officer of mine improved into "It's the drowned child dreads the water"), they are no sooner out of the reach of our balls, than they are "over the hills and far away," and it is truly astonishing to witness the rate they go at, when they settle down into one of their swing trots; I believe it would puzzle a horse to keep up with them even for the distance of a mile.

To see the remainder of a herd that has been attacked charge through their opponents, and then rush headlong through the jungle, bearing down in their course every opposing obstacle (like a pack of hounds running through a field of standing corn), is a spectacle to be viewed to admit of any adequate imagination of it.

The next herd that we find is, probably, located in a totally different position, and we form our tactics of attack accordingly; always remembering it is totally impossible to attack them in an open space, as they seldom ever act on the offensive, or even on the defensive, until they are forced to.

On this second occasion I was more fortunate than 
on the previous one, for having "tasted blood" in more than a figurative sense, I was determined to be revenged, and found that now the first excitement was over, and I better understood how to set about the business, it was quite as easy to take the matter coolly as not, and one obliging animal guessing my wishes at the moment, and anxious to put my abilities to the test, singled me out for a victim.

Curling his proboscis up under his head (not flourishing it in the air as all illustrations represent an elephant when rushing at an object) and bending its head half way down to the ground-a world of mischief peering out of that wicked little swinish eyeon he came at a quick trot at me.

He was soon within eight or ten paces-my gun had been at my shoulder covering the fatal spot from the moment he commenced the charge, and when another second would have brought him bodily on the top of me, one touch of the forefinger sent an ounceball crashing through his skull, and down he sunk without a struggle or a groan, his trunk nearly touching my feet.

The fall of the elephant is almost noiseless; instead of coming down like a house, plump on its side at once, with a concussion that one would suppose enough to cause a diminutive earthquake, it sinks gradually down, first on its knees, then on its belly, and, finally, rolls over as unconcernedly and gracefully as if it were going through some civilised evolutions under the managership of Mr. Hughes, or be- 
fore the enraptured audiences at Astley's "Cirque Olympique."

Sometimes, however, this operation is unhappily reversed, and instead of the animal rolling over, as in the present case, it falls to the lot of the aggressor, not only to roll over, but to be afterwards knelt upon (the favourite mode with the elephant-decidedly a "knee plus ultra" one-of putting an extinguisher on his foe), or torn limb from limb asunder.

These accidents, fortunately, are not frequent; and the only wonder seems to be how they are not so, when so many inexperienced youngsters venture out against wild elephants; the animals are extremely short-sighted, and when they charge down on a person, after having once marked him out, I believe they generally close their eyes, for it is very easy to jump on one side, and as the tiger never returns from his first spring, so do these animals keep charging ahead until they are again lost in the jungle.

The fate of the unfortunate Major Haddock, of the 97th Regiment, was a melancholy proof of the power and revenge of an elephant.

Having wounded one, and his barrels being all exhausted, his best chance of escape from the animal, which had now turned upon him, lay in dodging him round a small patch of jungle.

For half-an-hour this hide and seek game was kept on, until the major, imagining the elephant had attempted. a ruse by doubling round in the opposite 
direction, also changed his course, and ran directly into the brute's clutches !

Poor fellow ! he was dissected limb from limb, even to the smallest joint in his fingers, but not a bone, I believe, was broken.

An intimate young friend of mine was slaughtered, not many years ago, in consequence of his gun missing fire in the face of a magnificent tusk elephant. He was only nineteen years of age, and having passed a first-rate examination at Sandhurst, had come out under promise of being speedily gazetted to a regiment in the colony:- he was first knelt on, and then transfixed by the animal's tusks.

Some others have likewise been killed by these monsters; many I know have been horribly wounded, and experienced most fearful and providential escapes.

By the time that we have finished our second encounter, a feeling, if not of fatigue, at least of the necessity and agreeability of breakfast, forcos itself most obtrusively on our imagination ; and as we have wandered some five miles away from the bungalow during our excursion, and the sun is already high up over the mountains, and beginning to bring our garments into an unpleasant and dampish contiguity with our skin, it is straightway put to the vote whether another herd be attacked, or a retreat for that day be beaten to our jungle home.

Some fire-eating, never-satisfied youngster of the party forms probably the inglorious "minority of one" 
for carrying on the sport ail day, aad leaving bodily comforts till the morrow; - but as his views happily are singular, we make the best of our way homewards, each of our bearers carrying his master's trophies, of which he is quite as proud as if he had won it from the quondam owner himself.

A fine broad river, some twenty yards in width, runs about half a mile in rear of the bungalow; and, oh! the luxury of plunging into its depths,

Patulæ sub tegmine bamboo,

when the dangers and toils of the morning are over, and before commences the onslaught on the eontents of the huge packages that probably formed our bedstead on the previous night! - and afterwards, as we toddle home, enveloped in our kaleidoscopic dressing-gowns, to be met half-way by the matter-of-fact odour of fried eggs and bacon, beefsteaks, and coffee, is an extremely delicious treat under such circumstances, and well worth the reader's while (if he will only believe me) to start by the next overland mail, and experience it all in propriâ personâ.

After breakfast commences the misery of the day, and happy is the man who can bring himself to sit down and read until dinner-time.

For my own part I used to endeavour to kill the time by sleep, but no sooner had I arrived at the wished-for state of unconsciousness, than all the 
ghosts of all created elephants commenced wreaking summary vengeance on my body by every kind of horrible and incomprehensible means ; finally winding up their sports by a game of battledore and shuttlecock (which latter little article was personated of course by myself), until a smart concussion between the table and my head, accompanied by a violent fit of sneezing (caused by some ruffian having gratuitously administered a considerable quantity of "Irish blackguard"), would release me from the clutches of my elephantine inquisitors.

When the evening arrives, and it is again cool, the old man makes his re-appearance, and we either devote the remaining daylight to elephant-shooting or deerstalking, the place literally swarming with red deer, so much so, that sitting in the verandah of the bungalow, about dusk, one may kill as much venison in an hour or two as would keep him from starving for a twelvemonth.

A more amusing sport with these animals is coursing them with greyhounds (although this is excelled on the continent of India, where they are coursed with cheetahs), but as this carries us off our present subject, we must postpone it to a future chapter.

One day's elephant shooting varies so little from that of another, except in variety of escapes that we experience, that it would be an unfeeling action to drag the reader through a second day's labour; suffice 
it to add, that when the fortnight has come to a conclusion, as well as the provisions, we are not loth to return once more to a more civilised existence, congratulating ourselves on doing so in a whole skin, and on our possession of a huge display of the trophies of our prowess.

What becomes of the dead elephants no one appears to know, for although parties have followed parties without a week's intervention, the carcases of the slain have never been met with: but as the place is frequented by innumerable packs of jackals, it is not improbable that these lucky rascals come in for the most profitable part of the business, and clear off the mortal remains of the Monarch of the Jungle.

Elephants, being generally used throughout the island in the place of horses, for such purposes as they can be made available, such as government works, road and bridge-making, \&c., are every now and then captured in what is denominated "a Kraal," which is accomplished in this manner.

A particular spot of the island is selected where the kraal is to be erected, and a party of ladies and gentlemen, generally honoured by the presence of the governor, is invariably formed to witness this interesting proceeding.

A large space of ground is enclosed in a circle by 
natural trees (if it is possible to get them so situated), or by high poles, driven to a great depth into the ground; the intermediate spaces are then filled up by branches interwoven together so closely that it is impossible to see daylight through them. An aperture is left at one part, formed on the principle of that in a wire rat-cage, very easy to enter, but the reverse to get out at.

When all these arrangements are completed, the party ascend the neighbouring trees, where platforms are erected, furnished with chairs, from whence the spectators can view the whole proceedings unmolested.

A well-trained elephant is then conducted by its keeper into the kraal, and, on a given signal it commences a series of the most pitiful moanings and screechings imaginable; - presently, out trots an elephant frorn the jungle, and holds a vivâ voce intercourse with his fellow in distress. This makes the decoy double his lamentations, until the victim, perceiving the spot from whence the wailings proceed, at last discovers the aperture, and the next moment is in the trap.

One by one at first, but eventually in a string, the animals emerge from the jungle, and follow each other like a flock of sheep into the kraal.

As soon as this is full, the miserable traitor desists from his yellings, and then a number of natives, accustomed to the work, and furnished with coils of strong rope, enter amongst the captives, and tie the legs of 
two or three brutes together, whilst in a supremestate of alarm they remain huddled together in a heap, and apparently looking to each other for some luminous explanation as to where on earth they have got to. It never enters their heads to break down the kraal, which they might very easily accomplish.

The party located in the trees sometimes take their guns to get a shot at the animals before they enter the kraal, but this is not legitimate sport.

When each animal has been bound with cords to his next neighbour, other trained elephants are conducted to the scene of action, and one of these is intrusted with the tutelage of two or three of the recently captured ones, whom he immediately leads off into captivity captive ;-should they show any obstinacy or disinclination to accompany their new tutor, he inflicts such a belabouring on the miscreants with his proboscis, as soon makes them roar for mercy. The same means are adopted to teach them to work, except that one pupil is then placed between two preceptors, by which means he gets a double dose of correction administered, and a most amusing sight is it to witness this teaching their young ideas to work at the hands of their own species.

After having been properly trained, the cost of an elephant is, on the average, about $30 l$. The Ceylon elephant is considerably smaller than its African brother, nine or ten feet being the extreme height of the former.

I could fill an entire volume with anecdotes of these 
animals, that I have myself become acquainted with in my "Jaunts in the Jungle," but not wishing to stretch the indulgent reader's patience or credulity to a greater extent than it can conveniently bear, I will now make a most humble salaam, hoping that he may one day gain a better idea of the sport by practical experience than I have been able to convey to him on paper. 


\section{CHAPTER VII.}

MAJOR TOM ROGERS OF OURS;-AND HIS EXPLOITS."

HAving patronised the elephants to such a considerable extent, perhaps the reader would now have no objection " audire alteram partem," and spend halfan-hour in company with their bitterest antagonist, listening to a few of his personal anecdotes connected with the everlasting warfare he waged against the tribe.

That these brief sketches may meet the eye of many now living in Ceylon that knew our hero well, as also of those of his brethren in arms since scattered over the face of the globe, is not improba-

* The above story (or something not unlike it) I published some years since in the "Sporting Magazine," the editor whereof has kindly allowed me to re-use it, on acknowledging its former locality. 
ble-who will each in his turn, exclaim on perusing it, -

"Why was not such and such an escape, such and such a feat, such and such a daring act recorded ?"-

Most exemplary Reader ! - I can only say that of the multitude of anecdotes that I have eargerly listened to by the hour as I sat tête-à-tête at the dinner-table of poor Rogers (where, after a hard day's work, he would recount over claret and cheroots, the perils he had undergone, by far the greater part have escaped my recollection, solely from the fact of their being of such frequent occurrence that no ordinary memory could by any possibility have treasured them all up without adventitious aid; and little did I then think that the narrator was so soon and untimely to be taken from the scenes of his exploits, or many a daring act (the knowledge of which has sunk into the tomb with him) should have been noted down, and handed through these unpresuming little pages to posterity, as a memento of the extraordinary courage and the almost supernatural coolness in danger, of the subject of my present theme.

It would have puzzled a physiognomist to have looked in that pale pensive countenance, and to have read in those extremely mild, though manly, features the daring spirit that made its owner exclaim with Titus, "Perdidi Drem," unless his existence had been risked at all events once in the twenty-four 
hours, and to have discovered the characteristics of a temperament that, found beneath a few heaped-uplogs of wood, the roof of a native hut, or not unfrequently the branches of a banyan tree, a more welcome resting-place (particularly if indulged with the screeching serenade of a herd of elephants), than any luxurious establishment which his position in Ceylon would easily have enabled him to have indulged in ; and no less singular was it, that, living as he did, he should have retained such a uniform suavity of manners and disposition that distinguished him above all other men I ever knew.

The former were, I may almost say, ladylike : nor even was this extreme polish (although utterly devoid of foppishness) the least tarnished when in the depths of the jungle to what it was when called into play in the drawing-room, and so richly was the cream of human kindness instilled into his disposition, that I really believe he would have been glad to have begged an attacking elephant's pardon should he have happened by any mischance to have put him to a moment's more additional pain than necessary.

Moreover, being one of those persons who never could make an enemy, with the general, the sub, and the private, Tom Rogers was universally admired, beloved, and almost worshipped.

The opinion of him entertained by the elephants might have been in a directly inverse ratio.

His habitation was unique, particularly his dining- 
room. This he built himself at the distance of about twenty yards from his dwelling-house; and it contained most of his trophies.

It was a large square building: on either side of the doorway stood two huge elephants' heads, bleached as white as rain and sun could make them, and no doubt a source of terror to the unsophisticated little Niggers of the neighbourhood.

The interior was fancifully decorated with twelve pair of splendid elephants' tusks ; whilst the tushes formed various useful articles of furniture for keeping the doors open, or keeping down in its place a mosaic of carpeting of the skins of elk, deer, and bears; and then the elephants' tails (that in the absence of tusks had been brought home as trophies) which lay in admired confusion, here, there, and everywhere !-verily they would have re-tailed a "wilderness of elephants!"

But to see that room in its glory, when a party, having reached so far on their journey to or from the chief scene of elephant slaughter, had arrived to spend a day or two with its owner before or after they took him as their guide and participator in the object of their pursuit!-

We have perhaps experienced in merry England (would it were merrier!) the inexpressible delight we feel at the hospitable board of a fellow sportsman after a good day's work ; but it is nothing to what we feel when in the companionship of those with whom our 
life has been again and again in jeopardy-some, whose existence our own nerve has perchance saved in the "very nick of time ;" others, to whose unerring aim we owe the very possibility of our being then and there participators of the scene.

And mark the very cuisine - that hare, now diluted into "potags" at the head of the table, passed through no gameseller's hands, I warrant; neither did those jungle fowl, nor the venison cotelettes, nor the partridges, nor that undeniable snipe curry! the furnisher of the feast has procured them "without money and without price" (barring the cost of powder and shot): and as we make an attack on the "haunch," how vividly we recollect the onslaught made on us by a herd of elephants that our firing at that particular deer had frightened from their lethargy-and as, in that moment of self-gratulation, we take off the remainder of our glass of cold claret at a draught, we may almost fancy ourselves to have reached that state said to be denied to miserable sinners in this world, viz. - that of supreme, unalloyed happiness, where the "trail of the serpent" has so considerately exceptionised our especial pathway of existence, that if it has left a mark, it is so slight that we perceive it not.

Reader, if I wander from my subject, forgive me ; but the very thought of the interior of that room has diverted my ideas into the channel of "auld-langsyne," and to the companionship of many a noble 
fellow, whose society, like his of whom I write, is lost in death for ever!

On such occasions as Rogers would go on an elephant hunting expedition alone, he would merely mount his horse and gallop off into the jungle, leaving directions for his two servants (one a Cingalese and the other a Malay) to follow him to a fixed destination with his four guns; but it more generally happened that some "head man" of the district had arrived with the tidings of the propinquity of the elephants, and on such occasions the habitation of the Nigger would be arranged in his best style for the reception of his guest; this adornment usually consisting, as I before mentioned, in hanging the sides of a room with white drapery, so that a man was always " between the sheets" day and night.

I shall never forget Rogers returning home one evening from the "Park" to his quarters accompanied by every substantial trophy, in the shape of six young elephants as prisoners of war, the smallest about two feet in height, and the largest about four. These he occasionally allowed to have a run, when the young rascals would invariably toddle off to the old fruitwomen in the market, and a pretty havoc soon ensued amongst the plantains, oranges, and betel-nut.

They would go round levying black-mail; and woe betide the unfortunate vendor that did not suffer him or herself to be victimised to the heart's content of the depredator! 
However, their owner suffered most for these freaks, for he always made good the damages, which were generally multiplied, I expect, to rather an enormous extent.

I caught two of the animals one day in my bedroom, with an almost bran-new twenty-guinea rifle jacket in their clutches; one of them at one arm, and the other ripping off the braid by the yard to its inexpressible delight and self-gratification.-

(Didn't they just catch it?)

I must relate an anecdote told me by Major R-of a laughable circumstance that once befel him when elephant shooting in the North-west part of the Island.

He had accepted the invitation of a brother officer living thereat, to try a few days' hostilities against the elephants of that neighbourhood, and had arrived, after a hard day's sport, to within a mile or two of the bungalow where his host and hostess were awaiting his arrival, and where the dinner was either getting cold or exceedingly over-dressed, when, passing by a delightfully cool-looking river, he thought a plunge would be the most renovating luxury in existence ; so a plunge he determined to take, sending on his servants with his guns, and an intimation that in ten minutes he would be at home.

Stripping and placing his things very carefully on a stone, he began to luxuriate in the water. He was a capital swimmer, and had swam to some distance, when to 
his horror and dismay, on looking to the place where he had left his habiliments, he perceived a dozen monkeys "overhauling" his entire wardrobe !-one was putting its legs through the sleeves of his shirt; another, cramming its head into his trousers; a third trying to find out if any treasure was concealed in his boot; whilst the hat formed a source of wonderment and amusement to some two or three others who were endeavouring to unravel its mystery by unripping the lining and taking half-a-dozen bites out of the brim.

As soon as he regained his mental equilibrium (for the thing was so ridiculous as to make him laugh heartily, notwithstanding his disgust at seeing his garments turned to such vile uses), he made with all haste for the shore; but judge of his horror when he saw these "precious rascals" each catch up what he could lay hold of, and rattle off full speed into the jungle! not leaving poor Rogers even the vestige of an article of raiment wherewith to cover himself!

All he heard was a glorious chattering as they one by one disappeared, the last one lugging off his shirt, which, being rather awkward to carry, was continually tripping it up by getting between its legs.

Here was a pretty pickle for a Christian to be in under a broiling sun!-and here he was obliged to remain till the inmates of the bungalow, beginning to suspect some accident, came out in search, and 
found poor Rogers sitting up to his neck in water, in a frame of body and mind which we may conclude to be "more easily imagined than described."

It was in the noviciate of this extraordinary sportsman that the following occurrence took place in the neighbourhood of Trincomalee.

A frigate had arrived at the station, and as a matter of course its officers were fêted as well as the garrison would permit ; and it was finally arranged that the captain and as many as could get away on leave should make an excursion a few miles inland, in hopes of seeing some sport among the elephants, accompanied by many crack elephant-shots as a safeguard to the more inexperienced.

The important morning arrived, and a party of about twenty sallied forth to a place called Cottiar, which is generally a resort of all kinds of animals, and as hot and unhealthy a place as can well be found beneath the sun.

Elephants were soon found in all directions, so the party, to avoid spoiling each other's sport, by degrees began to separate into smaller parties of three or four, as the elephants became more plentiful.

About mid-day, Rogers found himself heading a party of half-a-dozen young "reefers," as well as the captain of the frigate ; and by the trumpetings and screechings of elephants in a small patch of jungle a-head, there was evidently good sport in store, by using caution and not being too much in a 
hurry. This was no easy matter to accomplish, however, with a parcel of jolly sailors; no sooner did they get sight of the stern of an elephant, than a most promiscuous volley was showered into the heads and tails of the astonished quadrupeds, without doing very material damage, for the next moment there was a simultaneous rush from the jungle, and away rattled the whole herd with the exception of one, which rushed straight at the captain of the frigate, and, seizing him in its trunk, made off round the plain!

It was the work of a moment; and had any one attempted to fire, the chances were greater in favour of his killing the man than the elephant. All looked on in dismay and horror, as they saw the old elephant pull up in its course every now and then, and seemingly attempt to crush its victim by kneeling on him; then holding him up in mid-air again, it would apparently exult in its conquest, and contemplate its prey with very much the same feelings as a cat does a disabled mouse.

Some pursued the animal, though that was perfectly useless, and might have only hastened the fate of the unfortunate man already in the jaws of death, when a miracle (for it can be deemed little short of one) saved his life when it was not worth an instant's purchase.

At this moment the elephant had got into a corner of the plain and was preparing to deal the death- 
blow, when Rogers perceived a young elephant emerge from the same patch of jungle as the others had previously done; and the evident uneasiness of mind that the young one evinced by its antics and its trumpetings soon made him suspect that it must be the calf of one of the animals that had started away, or, by no means an unlikely event, that it was its own mother that had, perhaps in defence of this very youngster, attacked Captain G-.

His plans were formed in an instant; and the stratagem showed the extraordinary presence of mind that never forsook him under the most trying circumstances.

Placing his two barrels within a foot of the young elephant's neck, he sent in both balls; then seizing another gun he planted one in the proboscis and one behind, so that neither hit any vital part.

Immediately that the youngster began to feel the smart, it set up the most awful yelling that ever mortal heard; it might have been audible for miles ; indeed, the wonder was that so much noise could come from so small a compass. Another moment, and the victim would have been torn limb from limb, but before the elephant had succeeded in falling on him the fearful moanings of its young one struck its ear.

Dropping its victim "like a hot potato," it rushed furiously to where its offspring was still making the welkin ring with the most hideous yells, but before 
it had reached it, a ball from Rogers's gun had laid it dead at his feet ; and then reloading, he at once put the young one out of its pain by sending a ball through its brain.

G- - was still lying on the ground to all appearance dead; but on reaching him, he was found to be only insensible, and most probably from the fearful revulsion of feeling when he found he had escaped such an imminent death. A little brandy-and-water soon revived him, but two broken ribs and a jungle fever (that confined him for weeks to his bed, and was as nearly putting an end to his existence as the elephant) gave lasting evidence of the treatment he had received when in the animal's power.

This, I believe, was one of Rogers's first adventures. The gentleman who acted the principal part is, to the best of my belief, now alive, and an Admiral in Her Majesty's Service.

The other occasion on which he was the means of saving a fellow creature's life happened some time after the event above narrated. Captain M-, of the - - Regiment, was one of an elephant party, made up, if I recollect rightly, for the amusement of the then Governor of the Island, Sir Edward Barnes.

A magnificent "tusker" was the object in view, who was guarded by the rest of the herd until every animal was shot down with the exception of itself, when the "tusker," thinking he might as well die fighting as standing still, rushed at M-—, and very 
soon had him in his proboscis. He then carried him off to some little distance, and, pinning him to the ground, attempted to crush him by kneeling on him. This his tusks (being very long) prevented him from doing, neither could he manage to transfix him with his tusks. It was almost an impossibility to get a shot at his head, being so close to M-_, therefore, several of the party, in hopes of getting the animal to turn round, fired at its body.

This but enraged it the more; and after nearly five minutes had elapsed, when nothing could save the almost lifeless captain but a coup-de-main, Rogers walked up to within two yards of the elephant, and lying down by the side of $\mathrm{M}-$ - placed the muzzle of his gun within an inch of the animal's forehead, and brought him down dead, almost on the top of its exhausted victim, who never recovered the shock, for he died very shortly after of a fever brought on in consequence.

On one occasion our hero had enjoyed some splendid sport with a herd of these animals; his four guns had all been discharged-when an unseen elephant made a charge at him from the skirts of the jungle. There was no help for it, except to run, and for one hundred yards and upwards Major Rogers kept just a-head, feeling at every step the animal's trunk trying to insinuate itself round his loins.

A turn round a tree gave him a momentary advantage, which he made the most of by springing 
up into the branches (he was as nimble as a cat, and as strong as a lion). One foot higher! and he would have been out of the elephant's reach; but before he had time to draw up his legs, the elephant had got one of them firmly clenched in the coils of his proboscis. Still Rogers pulled against him, thinking it better to have his leg wrenched from the socket than to fall back bodily in the animal's power. The struggle, however, did not last long, for, to the delight of the pursued and the chagrin of the pursuer, the Wellington boot that the former wore slipped off, extricated the leg, and saved the life of the wearer. (Heaven save us from such a boot-jack!)

The dilemma, however, did not end here ; for the elephant finding itself balked of its prey, after destroying the boot, took up its quarters beneath the branches, and kept its expected victim in the tree for twenty-four hours, when the tappal, or country postman, happening to pass by, Rogers gave him notice of his position, and on this being intimated to the nearest village, the elephant was frightened away by tom-toms, and yellings.

Had this occurred in a deserted part of the jungle, poor Rogers would indubitably have been starved to death in the tree!

Having given the reader one escape out of many, I may mention one anecdote to prove his perfect confidence in himself against this forest giant. 
At a dinner enjoyed by a party of sportsmen at Wilson Bungalow (among whom was the governor of the Island, the late Sir Robert Horton), the conversation turned upon elephant-shooting; when, to the astonishment of the company, Rogers backed himself at odds to kill two elephants with one ball at one discharge!

This being deemed impossible, was taken up all round the table, but the bet was gallantly won on the following day in this manner.

Rogers, knowing that an elephant invariably fell towards the side it was shot at (instead of away from the ball, as a person would naturally suppose), got information of the locality of several female elephants with their calves, who keep by the sides of their mothers in the same manner as we see foals at home; and placing himself in such a position as to get the calf between himself and the elephant he aimed at, he discharged the gun that under his steady eye and hand never failed to do its duty, when the old lady fell like a house on its progeny, crushing it to death under its own already lifeless mass of flesh, and every man who bet against the event saw it accomplished!

I will now conclude these anecdotes with quoting a portion of the contents of a note lying by me from Major Macready, who was at the time I was in the island, aidecamp to General Sir J. Wilson, and almost as staunch and gallant a foe to the elephantine race as Rogers himself : his few expressive words may tell 
more than all the foregoing pages. He says, "I remember perfectly the style in which he floored (speaking of an expeaition on which he accompanied Rogers), each by single shot, five out of six of a herd that he and I followed together, taking them so cleverly as each turned, and at the same time so quickly, that I was not able to fire a single shot, till, luckily, the two last that were left came round together ; but this was nothing to him."

The last accounts I heard of this extraordinary elephant slayer, previous to his lamentable end before narrated, were, that he had numbered Two THOUSAND elephants, slain by himself, and in future had made up his mind to keep no continued account. (For further particulars inquire of any officer of any regiment that has ever served in the island.)

Reader! such is a specimen of the once mighty Nimrod of Ceylon. Perhaps you were yourself fortunate enough to know the subject of the sketch; in such case you also know too well how unworthy a one it is.

Light be the turf on thy grave, poor Tom ! and may a long and worthy monument to thine excellent qualities survive thy existence in the hearts of thy fellows, who knew and loved thee! 


\section{CHAPTER VIII.}

MINOR DELECTABILITIES OF OUT-STATION LIFE.

AND now, most worthy reader, before I chaperon you among the scenes of the Pearl Fishery-where, under the protecting shadow of a huge talipot umbrella, we will recline in amicable vicinity, and gently insinuating ourselves (after the way of the world) into the individual affections of a vast pile of oysters heaped up within our reach, will soon become masters of the treasures

Embalm'd in the innermost shrines of their hearts,

and afterwards be "shellfish" enough ourselves (that's right, button up your pockets!*) to leave their plundered remains unburied on the plain. I say, before

* Could you, oh far-sighted reader! (or any body else) ever see the drift or wit of the extremely sapient saw of that lumbering old humbug, Dr. Johnson, "that a man who 
we do all this, you must mount your Arab, and join me in a rattling scurry after the spotted deer over the same plains on which we killed our elephants in the last chapter ; and also add all your little available in the way of lungs in making the Pusilarva hills resound with a louder echo to our "tantivy" as we view the stubborn old hog-deer chevying away before a pack of English foxhounds - then, having sent a ball through the brain of a buffalo intent on your destruction, we will leave this locality of the island to the next comers ; and, changing the scene,

We'll dive where the gardens of coral lie darkling;

that is to say, we won't dive in propriis personis, but whilst the. Malabar professionals execute that part of the business, we will be found ready to relieve them of their pearly spoils the moment they pop their heads out of water.

Deer coursing is a sport very little pursued in Ceylon, being, I suppose, voted "tame," after elephant shooting; still, in its way, it is a most exciting and pleasurable pastime, and, at all events, affords scope for a ride at racing pace over an uninterrupted plain. Major R—, the celebrated elephant shot mentioned in my last chapter, was particularly fond of this amuse-

would make a pun would pick a pocket?" Don't you vote it a most illiberal

Compounding for sins he was inclined to, By damning those he had no mind to? 
ment, and the dogs he used were a species of lurcher (half staghound, half greyhound, in appearance), and many a deer have I seen pulled down by them in the course of a couple of hours.

Mounting our horses as soon as it was light, we would start in any direction we choose, being certain of finding as many deer as we could possibly desire ; in short, the chief difficulty consisted in getting the hounds to settle down to one deer out of a herd of, probably, several hundreds. The only plan of doing this was by sending a man forward after we had viewed a herd, to head them when we had once started them, and so, by being thrown into confusion, we might by chance get one fellow to "take a line of his own," and then let slip at him.

It is a beautiful sight to behold herds upon herds of these graceful animals wandering forth, by the first light of morning, in quest of their daily food, some bounding at full gallop, of their own free will, over the plain, bound on some private pilgrimage of their own ; whilst others are strolling heedlessly about, or quietly grazing, until the rushing past of another herd arrests their attention, and as they stand with ears pricked and head erect, we take advantage of their abstraction to "bear down upon them," and away we go! horses, riders, dogs, and deer, at a rate that would soon "put a girdle round the earth," if kept up till that event-the niggers following as fast as they can on foot; and, to do them justice, I must 
say I never saw more long-winded, enduring fellows in my life, than the mountain population of the island.

I remember on one occasion being left in rather an awkward predicament with Major Rogers, during one of these deer-coursing expeditions.

We had started a splendid red deer, and had kept him going for three or four miles, apparently straight ahead, at racing pace, not even the obstacle of a broken bough intervening in our path to slacken our speed; when $\mathrm{R} \longrightarrow$, with his better experienced eye, perceived that the deer was about to make a turn off to the right, and, by way of "jockeying" me, he also made an échellon movement in the same direction; to complete which, however, to perfection, he had to pass beneath the branches of a large forest-tree.

Unfortunately, he miscalculated their height.

Still at a splitting gallop, he neared the lowest branches; there was no time for pulling up; so throwing himself flat along the neck of his horse (the only chance he had of escape), onwards he went.

I could see the horse, as he sprang under, dip to the utmost of his power, as if aware of the emergency; and, at the same moment, the lowest branch, which was about the thickness of my body, shaving R-'s hunting-cap, by the eighth of an inch, caught him across the shoulders just below the nape of the neck, as he lay along the horse's mane, and brought horse and rider to the ground with a fearful, stunning crash ! 
In a moment I was by his side, but not a groan could I hear, or any thing to indicate the least sign of life ; his pulse had ceased, and, of course, I concluded he was as dead as Demosthenes!

Not a soul either was within sight, and we had wandered into the most remote part of the plain, from which it would take a very clever person to retrace his steps to any particular point.

It was as awkward a predicament as ever I was in during the whole of my jungle experience. To lose one's way with a living man is bad enough; but imagine yourself, reader, lost to every trace of a civilised world, and left in a pathless wilderness, a lonely watcher of the dead! Till you have experienced such an ordeal (which I hope you never may) you can never have an idea of the awful, wild excitement of such a catastrophe.

Every thing that I could imagine, that might recall the vital spark, was tried, but in vain; and I might, as likely as not, have perished of starvation by the side of the lifeless man, or in the further wilderness of the plain, had not one of our dogs luckily discovered the spot where we were lying, and presently set up such a yelling and barking, as brought two of our followers to the spot.

Lifting the body, that we still supposed to be soulless, across the horse, we were guided back to the bungalow; and never felt I such pleasurable sensations in my existence as the first faint sigh that broke from 
the breast of the noble fellow whose supposed remains I was watching!

I had despatched a man forty miles for a surgeon, and in the evening of the second day he arrived to find the sufferer's collar-bone smashed, but the back-bone miraculously preserved. By careful treatment he in time perfectly recovered; but I think he abjured deer coursing afterwards-one thing I am very certain of, which is that $I$ did.-It's no joke watching dead men in a wilderness where you've lost your way, with the prospect of a three days' stock of carrion to live on, and then to lie down and die, and perhaps, never have the satisfaction of being picked up and owned afterwards!

The " neatest" sport I ever witnessed in pursuit of deer, is that followed on the sandy plains, on the Madras side of India, by the principal natives; viz., running down the antelope by means of cheetahs.

The cheetah, which is half leopard, half tiger, is reared tame in most cases, and is as docile and playful as a kitten.

It has generally the full run of the house where it is brought up, running and frisking about all day, and knocking over the juvenile little niggers that come in its way, with the most supreme good nature.

Having expressed a wish to a native potentate to see his animals exhibit in the field, the following day was appointed for a chase. 
About five o'clock in the morning, three queerlooking vehicles were drawn up at the door (something like our wains for carrying hay, only not so large), each being a platform of board, without sides of any description, mounted upon two wheels, from which a pole, fitted into a light kind of yoke, was attached to two bulls.

Presently out walked three cheetahs, each in charge of a keeper, and were forthwith severally located on the platforms, to which they were secured by a small dog chain.

My host then mounted the second car, leaving me to share the third with one of our feline companions, whilst our horses were led slowly behind.

In this way we proceeded about a mile, when I was obliged, in self-defence, to yell out to halt, as the continual jolting of the vehicle (it having no springs) had almost shaken my head off my shoulders ; in addition to which, whenever I lay flat along the platform to ease myself, the cheetah would at at once commence inflicting such a dose of licking on my face, to his nigger-keeper's most ineffable gratification, as well nigh suffocated me; so, to the "big man's" great astonishment, who was quietly sitting on his cart smoking his hookah all the while, I mounted the Arab he had furnished for my use, and proceeded forwards a great deal more at home, and with a chance of retaining my teeth in my head, and my head on my shoulders. 
Before arriving at the plain, we halted to place a hood over the heads of the cheetahs, after performing which we again moved on, and were soon on the vast range of sands.

Straining my eyes till they were nearly a quarter of an inch out of their sockets, in a vain attempt to catch the outline of some antelopes, that I was informed were just disclosing their antlers some mile ahead, I was told to make ready for a burst, if I wanted to be " in at the death."

At the same moment, one of the bandages was taken off a cheetah's eyes, when, drawing himself up on his platform, he took a deliberate look round the far horizon ; at last, his head was fixed, his eyes were lit up with the most vivid glare, and, with a bound, he was at once upon his errand.

Setting off at a gallop close behind him, I was presently saluted with a quiet sort of a growl, by way of admonition that I was to keep my distance; so falling into the rear about a quarter of a mile, I had an opportunity of watching well the tactics of the aggressor.

Instead of continuing on at the same pace at which he started, the nearer he approached the antelope, the more he slackened his pace, until, at length, he settled down into a slow, crouching walk, keeping his eyes still fixed on one point before him.

There was a small ridge of rising ground between us and the deer, and on reaching this he came to a 
dead stop, then sinking on his belly, he reconnoitred the herd, possibly picking out a fat fellow, before he made an attack on any of them singly.

In a second the heads of the antelopes were erect, sniffing the breeze; they evidently smelt mischief, for the next moment away bounded the herd with the cheetah at their heels (my Arab keeping up as best he could), at a rate that $I$ have never before or since seen any thing equal, except a swallow.

The locomotive platforms, that had followed us hitherto with their loads, were now disburdened of the cheetahs, whose hoods were removed, and themselves let loose after the flying foe.

It was a splendid sight, seeing the three animals in full chase together, after a herd of about twenty antelopes, although out of these twenty only three were fated-as the cheetah, after fixing his eye on one, never exchanges his object.

The chase did not last long ; I could plainly perceive the antelopes struggling to keep up the running through that wilderness of sand, in which their legs sank deeper than their fetlocks at each stride,-whilst the full, flat "pud" of the cheetah gave him a treble advantage, until, by degrees, they had receded within the reach of the nearest pursuer.

Without any apparent stopping or effort, the cheetah sprang on the neck of the animal he had marked out, who forthwith sank to the ground with its living burden. 
It was a magnificent spring ! for he was running directly in the victim's rear at the time he made the bound, consequently he cleared the whole length of the back of the antelope before he alighted on the fatal spot!

One of the attendants coming up, plunged a knife into the neck of the fallen quarry, which the cheetah immediately took advantage of by thrusting in his nose, and taking an apparently most gratifying and luxurious draught of the warm blood that had so lately animated the still gasping deer.

After this repast was finished, the gentleman was reconducted, in a very plethoric state, to his carriage, where having left him, wrapt in the intensest state of somnolency, we proceeded to look after the other animals, each of which we found in possession of an antelope, quietly keeping guard until its keeper should arrive, and reward its fidelity with the anticipated sanguinary draught.

The hog-deer derives its appellation from its characteristic attributes of that porcine quadruped.

It is a large, ungainly, savage brute, with a humped back, and carrying two tremendous tusks in its jaw, similar to those of the wild boar.

Whether it is really a breed of itself, I cannot say; but it is singular, though nevertheless true, that in 
all my jungle excursions among the brute creation, I have invariably seen the connecting link between animals of an entirely different species, and most perfectly pourtrayed from man downwards; that is to say, I have frequently met men (the Veddahs, for instance, mentioned in the second chapter of the "Jaunts"), that I should not have known from monkeys, and monkeys that more closely resembled men.

The reptile link has an immediate connexion with the quadruped in the crocodile, and so one can go on, ad infinitum. Where reason ceases, and mere instinct begins, I leave to metaphysicians, who have more spare time on their hands than I have, to determine.

The principal scene of my hostilities against the hog-deer was among the magnificent passes on the road from Kandy to Newera Ellia, near a place called Pusilarva, where I happened to have a brotherofficer stationed in charge of a company of Caffres engaged in road-making.

The climate here was delicious, nor did its sultriness entail a turning out in the middle of the night, in order to comfortably enjoy the sport of the morning, but it enabled one to lay in a substantial breakfast before undertaking whatever might be the order of the day.

Furnishing ourselves with a long, stout, pole a piece, to help us through the ravines and over the cataracts, we set out, accompanied by two couple of dogs (a 
remnant of the foxhounds that in days of yore had been imported by some exiled Nimrod, but which were now scattered throughout the island, in the habitations of the different dwellers at out-stations), and sending them in at the upper part of the mountain, to turn out any thing they might come across, we would keep up with them as best we could.

It would not be long before they scented a hogdeer, and a beautiful run would take place through the forest down to the valley; now and then lost to view, at other times seen tumbling headlong over rocks and broken ground, straight onwards sprang the deer, with the hounds in full cry in his wake; making the hills echo for miles with their deep-toned voices, whilst the sounds of our cheers, joining in chorus, must have slightly astonished every living thing within the range of hearing.

It was certainly rather astounding to view afterwards in cold blood the stupendous heights that we had dropped ourselves down from, in the ardour of the chase ; and chasms over the water-falls, that looked but as a gutter when we were in full pursuit, sent us round half a mile out of our way, on our return homewards.

I once saw a hog-deer at bay, and I never saw a more awkward customer in my life.

When the first hound attacked him he merely gave a supercilious toss of his head to all appearance, but in so doing he had ripped the dog open from the 
shoulder to the flank as if it had been done by a scythe.

The others springing simultaneously upon him, revenged the death of their comrade, although each dog was more or less lacerated.

The best plan, when going in pursuit of this animal, is to arm oneself with a pair of holster pistols, as they are just as likely to attack their human pursuer, as they are their canine enemies; besides which, when the dogs have brought the hog-deer to bay, it is much the more economical plan to put a ball through his head at once than to have a hospital full of wounded hounds to look after for the next month.

In this latter case there may be also a chance of saving the carcase of the animal for table, a proceeding I never saw accomplished yet-for the hounds, having once brought their quarry to the ground, never leave it while there is an ounce of flesh on its bones, from which circumstance I have no doubt that it possesses a peculiar delicacy, and I have frequently looked on in speechless grief at the demolition of the haunches by the dogs, knowing at the same time, that to interfere with their enjoyment of the repast, would in all probability be to subject myself to the same unsatisfactory process of becoming invisible. 


\section{CHAPTER IX.}

\section{DISAGREEABILITIES INCIDENTAL TO JUNGLE EXISTENCE.}

To give an unprejudiced opinion of which was the most dangerous animal to fall in with in the jungle I should decidedly say it was the buffalo.

These brutes are very plentiful in all parts of the island, but particularly so in the neighbourhood of Trincomalee, where shooting parties are sometimes got up for their destruction.

They are found lying in pools of stagnant water, with only their nostrils above the surface, or standing in the skirts of the jungle, and they do not always wait to be attacked before they commence hostile operations.

One person would have little chance against two or three buffaloes combined against him, as they offer no opportunity of getting a shot at them in their charge.

Springing out of the water as soon as they are aware of the vicinity of an enemy, they pick out the nearest stranger, and poking their noses straight for- 
ward, so that it is impossible to get at the forehead, they bear down upon him, and it requires a person to have all his wits about him to avoid coming in contact with their horns; which appendages I have frequently seen ten and twelve feet from tip to tip, and they are the only articles in the buffalo's possession worth shooting him for, the meat being coarse and unfit for table.

If you happen to have a friend you can depend upon in an engagement with a buffalo, your best plan is to stand the charge as courageously as you can, and thus give your comrade, who is at some little distance on your flank, a chance of a side shot just behind the animal's shoulder, which will, if fired by an experienced hand, find its way directly through the heart, and bring the adversary dead to the ground.

In excursions after elephants I have more than once had one of my followers ripped completely open by an unseen buffalo in the jungle, and when they are found singly they are more like mad brutes than any thing else, having most probably been driven from their herds for some reason, and henceforward doomed to the life of an outcast and an exile.

In self-defence I have shot many of the animals, but it became latterly a favourite trick of the natives when any one shot a buffalo to charge the person so shooting him with destroying his (the nigger's) private property; and in some parts of the island it is not a very easy matter to know a tame from a wild buffalo. 
How they are caught and tamed I am not aware, but it is certain that in some places they are so far half tamed by the natives as to be applicable to farm purposes, drawing carts, ploughing, \&c. ; and after their work is done, they are let loose to graze in the jungle, where they are joined by their brethren in a wild state, whom they sometimes retain in their company for their master's use, orreturn again themselves to a jungle life, till an industrious fit comes into their heads, and they think it time to patronise their owner's yoke.

It was on one of my excursions in pursuit of a dinner, that I had a very narrow escape from being ripped open by a buffalo.

Having shot a snipe close to the skirt of a wood, I went forward to pick him up, when out rushed a huge brute at me. Before I had time to put my gun to my shoulder, I had him on the top of me.

Pulling the trigger at random, we were the next moment rolling over each other on the ground-an amusement at which I certainly got second best off. Fortunately the charge (which was only No. 7, shot) had blown his eye in, and penetrated at once to the brain. With a few gasps he rolled over dead.

I had just picked myself up, and was congratulating myself on the narrowest escape I ever had in my life, when I perceived a party of men approaching me, headed by an Adigar, or chief man of the district. Never imagining their errand, 1 stayed still in hopes of further congratulations; which hopes were, how- 
ever, soon dispelled by the Native beginning a most lugubrious tale, that I had killed his only buffalo, the support of himself and family, with a long rigmarole of its genealogy, \&c.

It was in vain I explained to him I had shot the brute to save my life ; nothing would do but he must have twenty rix-dollars for the executed hope of the family, which of course I as strenuously resisted, and, to cut the matter short, trudged off as fast as I could.

The fellows followed me, however, and by their yellings had congregated the population of every village (one would imagine from the numbers) within a dozen miles; when finding they were now about two hundred to one, they took courage and stopped me.

Seeing that further resistance would only result in being thrown into the river adjoining, or murdered by the ruffiaus, I gave the Chief what money I had in my pocket, amounting to six or seven rixdollars (a rix-dollar being one shilling and sixpence), but this would not satisfy the fellow, so he proposed taking my gun till I redeemed it by paying the remaining seven dollars. This also I was forced to agree to, and then proceeded homewards as fast as possible-the safety valves of my temper, too, being " tied down," gave a stronger impetus to my progress.

As soon as I reached the bungalow, I threw the saddle across my horse, and in less than two hours had armed myself with a warrant from the nearest 
government agent, as well as furnished myself with a mounted messenger of the court to execute it.

It was night before I got back to quarters, so I reserved my revenge till the next day.

In case we might be resisted, six of the Malays accompanied us, armed with their rifles and creases, and in this way we set out for the Adigar's abode.

The first intimation that we had of our vicinity to it, was the continual popping of fire-arms ; presently the beating of tom-toms became audible; and as we came in view of the house, we perceived a large party around it heartily enjoying themselves.

It was evident the old brute was giving a feast on the occasion of the slaughter of the buffalo, and the lucky consequences following thereon to himself.

I could distinctly perceive him loading my own gun to celebrate his triumph ; so, waiting till he had discharged both barrels, I jumped unexpectedly upon hirn, and, having secured the gun, his Adigarship found hin-self immediately afterwards in the middle of an extensive bowl of curry, just served up, when the court messenger who accompanied me having picked him out and scraped him, produced the document in which the words "WrLLIAM IV." bore a prominent part; and the day after I argued my cause in court with the genius of a Cockburn, as will be allowed from the fact that I got back my own money, succeeded in getting the Adigar fined two hundred rix-dollars, and deprived of his rank for two years, which, in addition to his 
carrying his nose in a sling for a month or six weeks, gave him such a practical lesson in natural history (as far as knowing a tame buffalo from a wild one) as will no doubt last him until Buddha relieves him from all his earthly cares.

'There were times, however, when it was neither a very easy nor agreeable matter to take a stroll for a few miles by way of bringing home any delicacy one might fancy for the important service of the day's meal, and particularly so during the south-west monsoon, or rainy season, when for weeks together nothing appeared to be visible but one incessant torrent of rain-one everlasting drip, drip, drip, from the verandah roof, every now and then (by way of variety) carried by an occasional gust of wind into the sittingroom (there being no such luxuries as windows at outstations) and splashing one all over; during the middle of which, that "three gentlemen in one" (the cook, butler, and footman) would poke his headlooking blacker than ever-through the half-opened door, and add to one's happy frame of mind by the intelligence that

"Master no got dinner !"

Now there is something absolutely appallingterrific-dumb-foundering-in such words at such a season! It pictures desolation doubly desolate!

The cry of "house on fire!" or the information that the wife of your bosom-the sharer of your joys, sor- 
rows, and bread-and-butter-had tumbled down the well would be trifling indeed in comparison !

In the former case one might jump out of window, and inflict his agreeable companionship on the neighbour that was lucky enough to live nearest to him; whilst in the latter case he might, if of a philosophic turn of mind, console himself with the reflection that she -the sposa-ought to have "let well alone;" but however great a philosopher he may be, I doubt if any quantity or quality of his stock-in-trade would ever satisfactorily incorporate an imaginary dinner.

My own stock of the commodity never would, but invariably sent me out in a most unenviable plight, and trying to twist into a tune old Horace's

Jam satis terris nivis atque diræ, \&c.,

by way of keeping my spirits up.

Every diminutive rivulet, that yesterday a bird of Paradise might have walked across without holding up its tail, is now a roaring, boiling torrent !- every mountain ravine, delivering its flood of water into the valley beneath, seems to indicate the inevitability of a second destruction of the world ! whilst every symptom of life appears to have become suddenly extinct; until, possibly, a poor half-drowned missionary is spied, strolling along the banks of some flooded nullah, evidently on the same errand as myself, namely, that of obtaining the luxury of a dinner under difficulties; when plunging into the flood, and making way against it as 
best I can, the distance between us is soon reduced to within gun-shot, and then steadily sending into him the contents of both barrels, I am furnished with a hash for that day at least !

Christian reader! do not imagine me an ecclesiastical homicide! - The " missionary" of Ceylon (known by no other name than I am aware of) is a bird about the size of a turkey, but rarely made use of at table, except in case of dire necessity, as the present; but why it should not be generally eaten I do not know, for it is excellent-in my own case, the sauce it was eaten with, namely, the condensed appetite of a dozen wolves, may certainly have had something to do in flattering the imagination during a trial of its quality - but after all, what necessity is there for any body but the cook ever knowing of what hashes are composed, provided there exists the third part of a bottle of port, and the slightest dash of Worcestershire sauce in their conformation?

But to digress for a while from the artificial to the natural-from the precincts of the frying-"pan" to those of its sylvan namesake.

Will nobody ever have the enterprise to indulge the public with the "Illustrations of Ceylon," instead of eternally immortalising, over and over again, every ditch in Switzerland and pool in Westmoreland ?

If there is such a public-spirited individual, let him start at once for the heights of Hima-letta-wella before it is turned into a huge coffee garden-for the 
splendid pass of Kadaganarva, before they run the Ceylon Railway up it (at a gradient of two feet in one), and a thousand other places, whose precipitous grandeur, covered to the very apex with the most luxuriant and varied foliage imaginable, makes them more beautiful than any hitherto-explored scenery transmitted to us through continent tourists and copper-plate.

A series of Ceylon views would doubtless be an "immense hit," and I hereby (at the risk of advertisement duty) take the opportunity of offering my services to do all the "statistical, political, social, and moral" part of the business, for the consideration of half the profits of the work.

It must have been its picturesque scenic beauty that originally impressed people with the belief that Ceylon was the veritable site of the "real original" Garden of Eden, which is perpetuated by all the remarkable places being christened after our first mortal parent, such as "Adam's Peak," "Adam's Bridge," \&c. How far the geographical part of the theory holds good, I never sought to inquire.

The variety of the scenery makes it remarkably striking.

Lying at the foot of the most precipitous mountains are numerous plains, divided by streams, or ranges of cocoa-nut or palmyra-trees, and studded at intervals with the large forest or banyan-tree, as regularly as an English domain might be under the hands of the most tasteful artiste. 
Unfortunately, there are no fish in the rivers; or, if there are, the water-fowl monopolise them (an exceedingly scaly proceeding on their part), for it never fell to my lot to catch or cook one.

The cocoa-nut trees are besieged night and morning by a party of Cingalese, who manage to extract what they call "toddy" from the cocoa-nut, in large earthenware pitchers which are hung up during the night to catch the exuding fluid; and this, after being fermented, becomes arrack-Ceylon arrack-a most miserable substitute for execrably bad whiskey, at the very best.

However, they manage to get drunk on it, so it answers the desired end.

The pine-apples are the greatest luxury of all the indigenous wild fruit of the jungle, their flavour being excellent, and the cost of the fruit only the trouble of twisting it out of the ground. If they are bought out of the bazaar (or market), however, they are of a superior sort, and reach the price of two or three pice (about a penny), their value being also materially enhanced by the additional advantage of a "polish" from the vendor's head-gear, or petticoat, but never even with this additional lustre do they rise higher in the scale of worth than the unpresuming "murphy" in the neighbouring basket.

The roads through the interior of the island, where they form the principal thorough-fare, are generally in tolerable travelling order, except that every now and 
then after very wet weather, a land-slip takes place here and there, leaving a chasm of some twenty feet in the roadway-of which some bullock-cart, loaded with baggage or merchandise, takes advantage when travelling by night, to make a short cut to the bottom, carrying its driver (who is most probably snoring in the interior) along with it. The whole concern, as a matter of course, being completely "pulpified" on reaching the bottom.

From Kandy to Colombo there is a so-called "mail-coach," and the rate at which the horses trot down the Kadaganarva Pass, with a precipice on one side of at least a thousand feet, without the slightest fence of any sort, makes one cling on to the sides of the vehicle with most affectionate tenacity.

After all, the pleasantest and most independent way of travelling, when subject to such jungle casualties, is on foot;-and I would gladly take the reader back to head-quarters through a hitherto almost unexplored country, did I not suspect he has had a sufficient dose of the jungle, at least for the present season.

Having visited the summit of Hima-letta-wella (where, if he prefers, he may remain till the end of his days lost in admiration of the scenery), we will retrace our steps homewards.

On the top of this mountain, standing about 8000 feet above the level of the sea, is a small military outpost; and as it was but eight miles from the fort where 
my out-station experience was gained, I used in a manner to make it a country-seat, by spending therein all my unoccupied time.

The view from the summit was not to be equalled even in Ceylon for extent or magnificence.

The two or three forts in sight in the distance appeared like so many pill-boxes, although the area of each was in reality large enough to have contained two or three thousand soldiers; and the idea, as one looked down upon them and reflected that they were inhabited by human beings, imparted a very contemptible notion of the pigmy race of man.

It required no great stretch of fancy in the beholder-parva solens componere magnis-to make the scene before him appear a perfect world in miniature, or to imagine himself a second Gulliver among the Lilliputians, when he considered that the invisible " dots" within the said pill-boxes were placed there (dressed in red cloth) to keep in order other little dots (whose original fatherland it was) if they became obstreperous, or expressed the slightest desire of possessing and governing the territory allotted to them from the beginning of creation, or, at least, since its distribution, and then the mind would extend the simile to the world, and laugh to think it under the dominion of these less than mites even through a telescope -to think that similar "dots" were hanging other "dots" - big " dots" bullying little "dots" _ "dots" 
in trowsers making themselves agreeable "dots" to "dots" in petticoats-whilst various industrious " dots" were hard at work writing magazine articles for other more favoured "dots" to read !

The idea may appear ridiculous enough on paper, but if the reader has ever surveyed his species through a " minifying" glass, and allowed his imagination (if he has any) to run riot for a while, I have no doubt he has, moreover, been rewarded by a spontaneous and hearty "guffaw" at its ludicrous conjurations.

How much altered the scenery may have been, since the importation of a herd of coffee-planters, I luckily did not stay long enough to observe ; but I can fancy what the ineffable ecstasy of the monkeys will be, when they find themselves enveloped in a wilderness of red coffee berries !

Our near approach to civilisation is invariably indicated by the appearance of the Cingalese pedlars, known by the appellation of "moormen," a fine, handsome race of copper-coloured fellows-in appearance half Arab, half Parsee,-who spend their whole existence in hawking about for sale precious stones, such as sapphires, rubies, garnets, moon-stones, cinnamon-stones, \&c. ; and remarkably cheap they sell them;-where they obtain them from, I was never inquisitive enough to ascertain, always concluding, as a matter of fact, that they stole them; if, however, I libelled the worthies by the supposition, they have 
had their revenge by pretty considerably cheating me in extreme youth.

The first day's return to head-quarters was with me, I well remember, a marked one in life's calendar, by involving myself in rather an awkward predicament, owing to my sight-seeing propensities; it gave me an opportunity, however, of witnessing how apathetically the Cingalese (who, in minor points of view, are such arrant cowards) could make their exit from the world.

Hearing that there were two natives to be hanged, (and always being myself of a philanthropic disposition, ) I naturally expressed a desire to view the ceremony, which was instantly gratified by the regimental surgeon saying that his carriage was at the door, and as he was going to the spot, I might accompany him; so we started together.

We soon reached the outskirts of the crowd, and perceived the scaffold at some distance, erected in the centre of the market-place.

At last I ventured to hint that we were quite close enough to the scene of action to be altogether agreeable, and begged and entreated the doctor to stop, but all to no effect; and I need not attempt to describe the intensity of my horror, as we "pulled up" at the very steps of the gallows!

I now discovered that my chaperon had come on $d u t y$, to see that the fellows were sus. per coll. until 
defunct ; and fain would I have beaten a most inglorious retreat, if there had appeared the slightest loophole of escape ; but I was completely hemmed in, and on the platform before well aware of it.

Trying, by every possible means, to screw my courage to the sticking-point, I conjured up in my mind's eye all the fellows I had seen killed by wildbeasts, \&c., in the jungle ; but it oozed out of my fingers' ends faster than it entered my heart.

Shortly, a murmur and motion in the crowd betokened the advent of the murderers (father and son) and, seated in a cart covered with black cloth, I presently perceived the two criminals, grubbing away at curry and rice, out of two large bowls, as if their lives depended on the issue!

Even when arrived at the foot of the drop, they did not budge until they had finished the last morsel, and when this was accomplished, they looked as if they had consummated a most glorious action; and then-_all I remember is, trying to look desperately savage, and that I did not faint; but if ever I go an inch hereafter to see my worst enemy throttled, may his ghost-

But, no !-I am no Jephthah-I hate rash vows-. 


\section{CHAPTER X.}

\section{A "PLEASANT VOYAGE."}

I HAD long looked forward with a large stock of anticipated delight to the coming of my "tour" of duty to accompany the detachment annually sent for the protection of the oysters to Aripo, the scene of the pearl fishery, in the northern part of Ceylon; and tremendously Cleopatra-ish were the ideas my simplicity had imbibed of the profusion of pearls with which every spare receptacle I possessed was to be loaded on my return to head-quarters.

How far my expectations were realised may be conjectured, in some measure, by the assurance on my part that rather than undergo such an ordeal again, I would comfortably sit myself down and behold, with the most genuine unconcern, all the oysters that dwell beneath the waters under the earth deliberately walk from their deep sea home, and incontinently cast their pearly treasures into the face of each individual "swine" in Christendom, before I 
would budge one inch in the direction of Aripo, to avert such a precious calamity, or such a porcine insult.

Commenced with starvation, succeeded by shipwreck, and concluded by a fever-two months of my life were victimised for the sake of these ungrateful shell-fish, of which months the reader shall have a passing view, lest he, too, in some unguarded hour, should be tempted to risk his life and health by a voluntary visit to the Sierra Leone of Ceylon.

Ten o'clock on a very dark night saw me, accompanied by a brother officer and thirty men of Ceylon Rifles, safely lodged on board a schooner bespoken for our voyage to Aripo; the time of accomplishing which journey was supposed to occupy about two days at the utmost-and at eleven P. M. we were going through the water gloriously; although, apparently, directly into an American whaler that was lying at anchor in unconscious innocence just a-head of us.

In another second there was a crash, but immediately after away we went again, rather curiously decorated with a flying jib-boom and its appendages, doing duty at our foremast-head for a pendant.

The Yankees had not observed us, so we made ourselves as happy under the circumstances as we could.

It was about two hours afterwards that we were alarmed by some hideous shouts, apparently issuing from the sea under our taffrail, as, the wind having died away, we were slowly progressing through 
the water, which presently manifested their origin in a boat-load of Yankees, come to look after their missing jib-boom.

It soon became a matter of difference of opinion between their boat's-crew and ourselves as to whether we should "back our fore-topsail," and let them overhaul us or not, and considering it afforded a special demonstration of juvenile valour (being then hardly eighteen) and of displaying it to the troops in charge, 1 soon had thirty rifles, with bayonets fixed, on deck, to dispute any interference with the "oyster guard," whose honour, as forming a part of her majesty's service, I felt myself bound to protect; so that the reader will not wonder, that, when the Yankee mate had reached the main-channels of our vessel and got a footing there, he dropped " like a hot potato" back again into his own boat, and gave orders for an instant retreat; whilst we, catching at the moment the land wind, which then came off shore, toddled away like a crab in a hurry, making two miles to leeward to every one we made a-head.

We did not know this at the time, fortunately.

I say fortunately, as, had we been aware of it, we might have prevented it, and thus have come in for an action for damages laid at our door for a forcible expulsion of our midnight visitors, who after waiting ten days for us, and then feeling satisfied we had gone to the bottom (at which, no doubt, they were almost as delighted as if they had secured their damages), thought it no use wasting any more time, and left the 
case till they should revisit the island-when I hope they may get it.

Awaking at daylight next morning, great was the surprise of every one to find himself out of sight of land:

On we went all through the day, yet no shore became visible.

At last, it was supposed we had got round Cape Comorin, and were drifting off into the South Pacific; a very pleasant prospect for a Christian with two days' provisions on board!

On the following morning we were exactly in the same predicament; and to make matters worse, at noon one of those intense, breathless, calms came on, that one sees nowhere but in the tropics, stagnant and death-like-whilst the rays of the sun, from overhead, came down with the intensity of being concentrated into a focus; actually boiling up the tar between the deck planks, and flaying the skin completely off our faces and arms, it being impossible to go below, and equally impossible to bear any thing in the shape of clothing (except necessaries) on account of the stifling sultriness of the atmosphere.

Not a breath of wind was stirring, Dread the hush as of the graveIn the weary waste of waters, Not the lifting of a wave !

Our crew consisted of the captain, a seaman, and a boy; and on the evening of the second day the latter was seized with cholera. 
He lived in tortures for about twelve hours, and as soon as the breath was out of his body (cholera then becoming infectious), we fastened a bolt of pig-iron to his corpse, and launched him over the gangway.

In a second, the water that had been so deadly calm before, was broken into a perfect whirlpool of foam, and the sharp dorsal fins of a wilderness of sharks, fighting for the prize, soon pointed out to us the dead boy's destiny.

In the morning of that day, the soldiers of their own accord had put themselves on quarter rations of rice-there was no want of water at present; but as for the commissariat of my brother officer and myself, it had entirely vanished; leaving us only a pound or two of brown sugar, and a bottle of pickled onions to live on, till we were rescued from our present position.

It was now apparently a matter of difficulty to work the ship with so few hands; and I was not a little surprised when the native officer of the men on board came up, and informed me that at least twenty out of the thirty soldiers, were as much in their element afloat as on the parade-ground, having been pirates in the Straits of Malacca during their earlier years!

()nly too glad to secure their continued good-will and allegiance, I let them take the helm, make sail, and manage the vessel; and if they had not done so, Heaven only knows what would have been our end.

As soon as the funeral was over (and a most unce- 
remonious one it was), we had a puff of wind (enough to keep up the favourite superstition of sailors) but at night it died away again, and two days and nights had lapsed lingeringly into the grave of Time-spent by all in an agony of suspense, starvation, and painbefore a black cloud burst over us, and cooled our burning and bursting veins; during this time the men had about three thimblesful of boiled rice each day, whilst we tasted nothing but the brown sugar and pickles.

It was now the fifth day, and things were beginning to assume a most serious aspect; so, holding a council of war, we determined to turn the vessel's head directly north, and the first land we saw to run for ; then, disembarking with loaded rifles, to plunder the place of all that was to be found therein, and having found out our locality, to put to sea again.

At last the south-west monsoon began to creep towards us over the waters, till catching our sails, we ran along before it at the rate of about six knots an hour.

At noon there was a cry from the foretop-masthead of "land right ahead!" and in half an hour every man was on deck and accoutred in readiness for an expedition.

The land lay so exceedingly low that at the time it was first seen we must have been within six miles of it, and as we neared it quickly and silently not a breath or sound was heard on deck from a man on board; each stood fixed and noiseless as a statue, straining his 
eyes to catch the sight of a dwelling or any living thing, but in vain.

A sharp, harsh, grating sound, as if our chain-cable had run out by accident, a fearful shock, and a rush of waves astern, was the event of a moment, and we were stranded on a coral reef !

Luckily, we had one nut-shell of a boat, which was at once got out, and the land being little more than a mile ahead, the first party pulled off for it.

At times I could see them get out of the boat on to the reef, and lift her over the shallows (so little water was there on their summit) and as they lowered her again she would be in forty or fifty fathoms.

We soon ascertained our position to be such that it was impossible for us to sink; we had run into a perfect channel, or bed of coral, to the whole length of our keel, so it was some consolation to know that we might yet live to be hanged, although our chance of getting off after the plunder that we anticipated, was most completely knocked in the head.

After landing the men in six journeys, I found myself on shore, on a low sandy island, covered with a few shrubs only, and which might have been circumambulated in a quarter of an hour.

This was another poser, for had it been one of the Cannibal Islands themselves, I doubt if the adage of " $\mathrm{dog}$ not eating dog" would be longer tenable, nor would I have given much for the pickings of his majesty's bones, after we had been allowed a first attack on him. 
Taking my gun, I commenced a survey, sending the men in all directions to hunt for any living thing they might find.

At last I discovered a house in the very centre of the island, and made my way straight for it ; but on arriving at it, found it was only a temple, most probably erected by some shipwrecked fishermen or sailors out of the coarse timber of their wreck, \&c., and after feeling the images carefully, to ascertain if they might chance to be constructed of any thing edible (how we wished even to find a gingerbread idol amongst them;-wouldn't we have gobbled down his godship?) we took our departure in sorrow and despair.

Two very lean sparrows flitted across our path, but they looked so wretchedly poor that I let them depart in peace.

On arriving at the beach where we had landed, I was nonplus-sed by observing all the Malays stretched out in skirmishing order along the shore on their hands and knees, and apparently digging some hidden treasures from under the sand, which operation was presently elucidated by observing several forage caps full of cockles by the sides of some of the soldiers.

As the landing from the ship had taken up many hours, it was now beginning to grow dark, so the bugle sounded the retreat, and every man brought in his cap, handkerchief, and hands, full of these shellfish (not a man, I firmly believe, having himself eaten 
one, until his share was afterwards doled out to him), and having piled them in a heap on the sand, they formed a circle around, and chaunted a hymn to Allah, before commencing the repast.

The moon had risen above the waters in one round ball of fire, apparently of double the size that it assumes in our own hemisphere, and as its beams fell on the white sails of the stranded ship in the distance, and illumined our shipwrecked group in their adoration of the Prophet, it left an impression on my mind that a thousand years of earthly vicissitudes could never efface.

I could not help imagining, however, how different might probably have been the scene, had I been thrown in such a situation with the denizens of more civilised nations, with whom, I am much inclined to believe, Allah would have been far less noticed than the cockles, and when again, I fear, it might have been said with truth, "There are not found that return to give glory to God, save this stranger."

For the following two days and a half I was as staunch as a Mahommedan (barring the giving up of wine), as ever dreamt of the black eyes of a houri.

The hymn over, the men were ranged in a row, and about a quart of cockles dealt out to each-(I see, my dear reader, you are dying to perpetrate a pun, and to affirm that there could be no more appropriate food for "muscle-men" than cockles); and for my own part, I candidly own to have never en- 
joyed a repast so deliciously as I did that hatful of raw shell-fish, every one of which was swallowed alive of course, after being wrenched open by being placed back to back with its neighbour, and slightly twisted round-a proceeding that at once revealed the plump interior of both at the same time.

We had brought a large barrel of water ashore with us, so, having made the most sumptuous repast we had tasted for many a day, we were proceeding to lose sight of our troubles in sleep, when the cry of "a sail" brought us at once to our feet again, and sure enough our hymn was not unheeded, for scarcely three miles off was a schooner scudding past the island at the rate of six or seven knots an hour !

In a second I had the rifles, which were already loaded, unpiled - and, at the word of command, thirty reports rang simultaneously through the still night air, followed by a cheer that might vie in extent of sound with the preceding explosion, and which we soon had the unspeakable gratification of seeing answered by a blue light on board.

Continuing to fire off rifles at intervals, we gave notice of whereabouts we were located, and the schooner having come as close to the land as she safely could, sent a boat on shore to see who we were, and what was the matter.

She proved to have been one of the last vessels that had proceeded upwards with troops, now on her return; but so devotedly were we all engaged with our 
treat at the time she was passing, that it was next to a miracle she had not sailed by unnoticed. We moreover learnt that we were on one of those very small islands at the head of the Gulf of Manarr, and not six hours' sail from our destination.

As it was too late to embark at once, owing to the dangerous nature of the coast and our ignorance of the tides, we waited until daylight before the first boat-load put off, and at 10 A.M. we were on our way once more to the fishery, leaving the Bassein Merchant (for such was the title of the tub that had got us into this scrape), on the reef; but whether the "merchant" ever resumed business, or became a bank-(of coral)rupt, I neither know nor care.

At five o'clock that evening we were received in the open arms of our more fortunate comrades, who had long given us up as having gone to the bottom, and the feeling of delight at our preservation was such as I never saw equalled; the English soldiers vying with the Malays as to who could show most attention to the rescued Riflemen, and if the seductive voice of John Bull, in the proffer of his wine-cup that night, did cause certain transgressions of the commands of "Allah," all I can say is, that Allah must be a much more unforgiving and stubborn old deity than I take him for, if he did not forgive the offence in respect of the occasion.

Reader, my good fellow, would you enjoy a dinner in perfection?-if so, l'll give you a never failing re- 
ceipt, viz., lock yourself up for a week with a quart bowl of brown sugar and a jar of pickled onions as your sole companions, and if on the seventh day you don't become aware of the enjoyment of a Christianlike feed, all I can say is that you will be a great deal better out of this world than in it. 


\section{CHAPTER XI.}

“WAR TO THE KNIFE" WITH THE PEARL OYSTERS OF ARIPO.

But now for the oysters.

From the dirty little village of Aripo (which is only populated, I believe, during the pearl fishery, and which seems to be founded entirely upon monstrous oyster shells), about two hundred boats start out to sea every morning, each boat carrying two divers, two assistants, and a Malay rifleman with loaded arms, to protect the oysters from being robbed of their treasures before they have reached the shore.

When this fleet has arrived at its destination, about four miles from land, the diving commences; and as there is always an armed vessel stationed in the neighbourhood for the protection of the oyster boats, a person may look on from under an awning therein, and enjoy the whole scene in a very dolce far niente sort of way.

To enable the divers to reach the bottom of the sea, which is from ten to twenty fathoms in depth where 
the oysters are found, a long rope is woven round a pulley at each boat's cross-trees, to the end of which is attached a large stone, weighing two or three hundred weight; this stone is poised over the side of the boat, and the diver standing upon it, and taking with him a basket (also attached on board by a rope), gives the word to "let go," and at once sinks with the stone to the bottom.

This is again wound up, and the diver is left below to scrape as many oysters as he can into the basket during his submarine sojourn.

When this is accomplished, he loosens his hold of the rock or sea-weed that he clings on to below with one hand whilst he fills the hamper with the other, and immediately shooting up to the surface is again taken on board, the hamper or basket full of oysters being hauled up at the same time. Then the second diver goes down, and so it goes on till 4 o'clock P.M., when the boats return with their freights.

Being personally acquainted with the gentleman who had the management of the fishery in the year I was stationed there, I used, when off duty, to go out in the government boat, which was fitted up with every convenience in the way of awnings, \&c., and taking every necessary luxury with me, in addition to a diver, I divided the day between feasting and hunting for pearls in the oysters which were brought up by this man especially for my own use, and many a lucky prize I sometimes came across. 
When the fishery was nearly over for the day, we used to give prizes to the man who would remain longest under water, and on one occasion I knew a man to remain below for one minute and fifty-eight seconds, but he was so exhausted when he reached the top, that it was a long time before he could be brought to.

All these divers were Malabars, and brought up to the habit of diving from their infancy, so I doubt if they are to be surpassed anywhere, although I well remember reading, in my younger days, in a standard work which, I believe, was an "Encyclopedia" in about thirty volumes, that it was usual for pearl divers to remain twenty minutes under water without inconvenience! an assertion that, for the benefit of others who may be impressed with the same idea imbibed from the same source, I should wish the promulgator to be requested to prove in his own person.

What makes me so well remember the circumstance, was my standing out at the time, singlehanded, in all the obstinacy of ten summers, against the "Encyclopedia," on the point; a piece of temerity that was chastised by a two hours' earlier dose of bed than usual, to my utter disgust.

As soon as the boats are sufficiently loaded with oysters, a sailing match takes place for the shore among them, and a very good idea of a monster regatta it gives one.

The troops on duty are now drawn out on the 
beach, to see that the oysters are not appropriated by any one, before being sold by auction, or placed in the government store.

This is a large quadrangular space, guarded by four lofty walls ; the floor being an inclined plane, intersected with numerous gutters, through which small streams of water are continually running from a reservoir, in which the oysters, not sold by auction, are placed to rot and open.

As soon, however, as the oysters have been landed, as many as possible are put up in small lots and sold; and a very amusing part of the business it constituted, being a complete lottery, as one might purchase five pounds' worth of oysters without being recompensed by a single pearl, whilst the private soldier investing his penny or twopence in the purchase of half a dozen, might find a prize valuable enough to purchase his discharge, and keep him in clover for the remainder of his existence.

I recollect one man (an English corporal) coming to me with a pearl he had extracted from his pennyworth of oysters, which was as large as a cherrystone, and for which he asked me five shillings. As I believed I could get the owner at least $500 l$. for it, I persuaded him to forthwith accompany me to a pearl merchant in the bazaar, who, on examining it, offered forty rupees (4l.) for it. Unfortunately, it was a black, discoloured, pearl, although perfectly round. Had it been white and transparent, he said he would have caught at it for 10,000 rupees $(1000 l$.), so much 
depends on the shape and transparency of a pearl in its value.

But determined to make a profit or loss in our own private dealings, each officer might be seen sitting outside his barrack-room every morning with about a couple of hundred oysters piled on one side of him, and a bucket of water on the other, backing his lot, to the arnount of his day's pay, to contain more pearls than that of his neighbour, while the witnessing the avidity with which every one wrenched open his oyster, in hopes of treasure, was most amusing.

Formerly the government used to keep all these oysters itself, and have them opened in the store by men chosen on purpose, instead of selling them by auction; but these fellows got so expert, that even although they were closely watched, they would manage to jerk a pearl from the oyster-shell into their mouths without being. detected, and swallow it; a proceeding, however, if discovered, that entailed a very summary mode of punishment under the hands of a native doctor.

The oysters that are not sold are placed in the reservoir before-mentioned that stands in the store, and here they die and open of themselves. The pearls then immediately drop from them, and are carried by the water continually flowing through the reservoir into the gutters, until they are caught by a small gauze network, through which the water passes, leaving the pearls behind, and they are then picked up in large quantities. 
Very few of these pearls, I understand, are sent home, all finding a sale on the coast of India, among the richer class of natives.

When the fishery is about half over, the nuisance commences.

All the oysters that have been placed in the government store to open, begin to putrify under the rays of a burning sun, and the stench surpasses any pestilence ever inflicted on the earth. Then commences fever, cholera, dysentery, and all the concomitant ills of foul air, filth, and heat.

For miles and miles in the jungle will the disgusting effluvia be carried in the direction of the wind, and to prevent being too nearly exposed to it, the barracks are situated at a distance of two miles from the place, yet even there it is at times intolerable, particularly at night.

Had the oysters been eatable, we might have assisted to lessen the number left to decay, but they never are eaten by natives or English, being very dissimilar to our own oysters, and few of them being smaller than a dessert-plate, so that one oyster, if a man were bold enough to make a trial, would make half a dozen patés, or an entire "scallop" of itself.

Our mess-room consisted of a tent erected on the sands, not at a great distance from the surf; and there being a tolerable supply of game in the neighbourhood, no sooner was the arduous morning occupation of pearl-hunting over, than an early "tiffin" 
would follow, and every one would sally forth in pursuit of adding some little delicacy to our table in the evening.

But, talking of delicacies !-I made a discovery there, that had I done the same at home, and been born a cook instead of an ensign, Carême himself would have done homage to me.

It happened one day, after having been out and finding nothing for several hours, that on tumbling up over some rocks to get a good view of the sea, I came upon an animal never encountered before in all my excursions, and which, at first, rather astonished me.

The first thing I did was to drop in a bullet over the shot already in the gun, and shoot him.

On coming up to the animal, I found, to my horror, that I had shot my own crest (a most unlucky omen, I should fancy), and a "Porcupine," in all the fretfulness of a hundred quills, lay dead before me.

However, I absolved my conscience for the murderous deed, by considering what an appropriate addition it would make, after being stuffed, to a family lobby; and advanced to lift him up to carry home for this purpose, a proceeding I found easier to imagine than to perform; until, by tying his legs together, and in this way slinging him across my gun, I managed to get along pretty comfortably, with the exception of a sharp prick or two now and then.

It was under these circumstances that I unluckily fell in with a large shooting party, and my staggering along with a porcupine on my shoulders formed a 
source of caricatures and jokes that never left me whilst I remained in the island.

A luminous idea now struck me, that, instead of having him stuffed, I would most decidedly eat him, (metamorphosing him from stuffée to stuffer), so ensconcing myself in a quiet nook of the Jungle, I soon stripped him of his quills, and having gained the cook's affection by a present of two rix-dollars, we put him into a pie, and served him up that night at mess!

I had the "helping" it, and passed it off as vealpie (as it most resembled that in appearance), and all I know is, that I began to be very much afraid I should have none left for myself, as every body present became a customer; at last, I did secure a morsel, and nothing more exquisitely delicious did I ever taste in my life-so excellent was it, that had there been a pie apiece, I believe they would have all been demolished-for the major, who was our commandant, and a great gourmand, immediately asked the mess-cook where he got his meat, which worthy immediately pointed at me, and said, "Gsaib, give it, present."

Of course every one looked to me for an explanation; as, how I could get better veal than any one else was a mystery.

I then told the party that it was "the porcupine;" and never shall I forget the horror depicted in most of their faces: some turned as pale as ghosts, and 
yelled for petits verres of cognac, whilst others tried to laugh at and disbelieve it.

However, so excellent was it, that I was determined, if possible, to have another pie, and the next day I found a nest of porcupines in the neighbourhood of the scene of the former one's destruction; and although, on the second production of the dish, I was only joined in the delicacy by a very "green" ensign, still, before a fortnight was over, one by one became a convert, and " $\mathrm{G}$ dish," or "porcupine pie," got to such a premiumthe demand exceeding the supply - that the animals became exhausted; and no more "materials" could be got within a dozen miles, the "fretful" animal having become, no doubt, too "crusty" to show out with only the prospect of a pie before him.

I here had an opportunity, one morning, of practically deciding the truth of the opposite theories, entertained by the celebrated Buffon and the showman of Bartholomew Fair notoriety, * as to the power of the porcupine of harpooning a distant object with his quills ; and I would just as soon stand as target for a toxopholite society, as I would before a society of porcupines, barring the distance.

A brother officer of mine had a spaniel completely

* For the benefit of the reader unacquainted with the view of the case held by this worthy, it may be as well to set it forth in his own eloquent and expressive words. Speaking of the porcupine he is showing, he says, "Buffoon says the little animal shoots his quills; but Buffoon is a fool and a liar. He no more shoots his quills than I my arms nor legs." 
transfixed with a porcupine's quill; and, although I did not personally see the quill shot, I saw the dog lying dead in the same place that it was shot at, with the quill driven about eight inches in, behind the shoulder, and completely drilling a hole through the heart, as it afterwards proved on dissecting the dog.

It was perfectly impossible that the quill could have been thus forced into the body of the dog without being shot at him with very considerable force ; and my friend, who was close by the animal at the moment, asserted that the dog was at least a couple of feet off from the porcupine at the time, and that three or four quills flew off in different directions at the same instant.

As this is a matter finding more infidels and heretics than true believers, I have thus particularised it, and am ready to uphold my case (by " $y^{e}$ wager of battel," if he chooses) with any sceptical heathen in Christendom.

The country in the vicinity of Aripo is flat and uninteresting, although in penetrating it to the extent of two or three miles there is no lack of game, such as hares, partridges, snipes, \&c.

Crocodiles poked their noses out of every pool one came across, but they would never attack one, and if a shot was sent at their heads they would merely disappear altogether until the danger was passed.

Tortoises in dozens used to cross our path, but they were very small and perfectly useless. 
A few miles further inland is a celebrated monkey territory, where the tribe grow to a larger size than anywhere else, and where a story is told, and I believe truly, of a certain functionary in the island who had the misfortune to fire at one of the animals in hope of carrying home his carcase to be stuffed.

He had no sooner fired than the whole forest rang with the most heart-piercing cries, and in a very short space of time he saw an army of monkeys, some standing nearly five feet in height, arrayed against him, whilst some attended to their wounded brother.

Of course he lost no time in beating a retreat, but was soon overtaken by the exasperated animals, one of whom walked deliberately up to him, and took away his gun, and having thus punished him, allowed him to depart in a whole skin, which was more than he deserved, for there is something so cold-blooded, so useless, so uncalled-for a slaughter of the prototype of man in a poor defenceless monkey, that a person ought at least to be half hanged for such an act.

(If you happen to know any Ceylon man, my dear reader, mention the story to him, and he will tell you the person's name - if you are inquisitive.)

The oysters at last coming to an end-or, being tired of a game at which there was no reciprocal fun -having issued marching orders to all that survived, the place is again deserted by every one except the troops, who remain till the last captured oyster is thoroughly decomposed, and then, in case they (the 
troops) are not in the same state themselves, are permitted to quit the scene until their tour of duty comes round again; but as soon as the fishery is over the most dangerous time begins, for the putridity of millions upon millions of oysters impregnates the air to such a degree, that I would defy the most obstinate limpet that ever clung on to a rock to escape going into hospital, owing to the effluvia.

Men drop dead on duty from its effects; shrubs are entirely withered; and, as in

The Dead Sea air,

Nothing lives that enters there ;-

Consequently, whilst yet it wanted a week or ten days to the expected recall of the troops, I found myself carried over the waves in one of the native catamarans in the direction of home, with as respectable a specimen of a jungle-fever on me as one might be contented with for the remainder of his life; and after having undergone three months' suspension between two worlds, my ghost was at length allowed to revisit the mess-room of the regiment, where, by dint of making itself perfectly at home, it in time assumed a more tangible and corporeal substance, which, it is happy to say, it now enjoys, and means to retain as long as it possibly can. 


\section{CHAPTER XII.}

CONCLUSION.

Reader ! our "Jaunts in the Jungle" are at an end-at all events, for the present-and their existence would have terminated with the last chapter, had not my publishers "begged to decline the honour of chaperoning such a ninety-nine legged centipede as an eleven Chapter-ed book," whilst my exemplary printer (already worked into a state of desperation by "proof" persecution), intimates "that rather than allow this enfant terrible to issue from his nursery curtailed of its fair proportions, he would (on his honour, as a component part of that mighty engine, ' the press,') incontinently pack up his carpet bag, and undergo a private 'Jaunt' of his own, against any wild animal hitherto invented."

Under such circumstances (having struggled desperately, yet vainly, to make the Preface do duty for Chapter XII.), I can only constitute you, my excellent Reader (if you have already waded so far), a scapegoat on the present occasion, and making 
my lowest salaam, beg to suggest how much more gratified I should have been, had you corporeally, as well as mentally, accompanied me throughout our little forest-pilgrimage.

And this for two reasons - charitable, and selfish.

In the first place-charitably-you, wise as you may be already, would doubtless be a still far wiser person in your generation, and not half so apt, as you are, to "pooh-pooh," and disbelieve all the tales, which not having been a witness of yourself, you are inclined to attribute to the inventive faculties of your poor erring brother mortals-whilst in the second, or selfish place - I (delightful idea!) can half imagine the agreeable acquaintanceship I should have formed-the pleasure with which-in these cold wintry times and scenes-we might toast our toes over a roaring Christmas fire, remembering our tropical actions at "just this time" so many years ago-recounting our escapes-reslaying our forest foes-and congratulating one another that we were now as we are-enjoying the "mens sana in corpore sano"- the faculties of youth in a frame unscathed- and attributing thereof the cause-that

We've trusted aye to Providence And sae will we yet !

C. WHITING, BEAUFORT HOUSE, STRAND. 




\section{DAY USE}

RETURN TO DESK FROM WHICH BORROW ED

\section{LOAN DEPT.}

This book is due on the last date stamped below, or on the date to which renewed. Renewed books are subject to immediate recall.

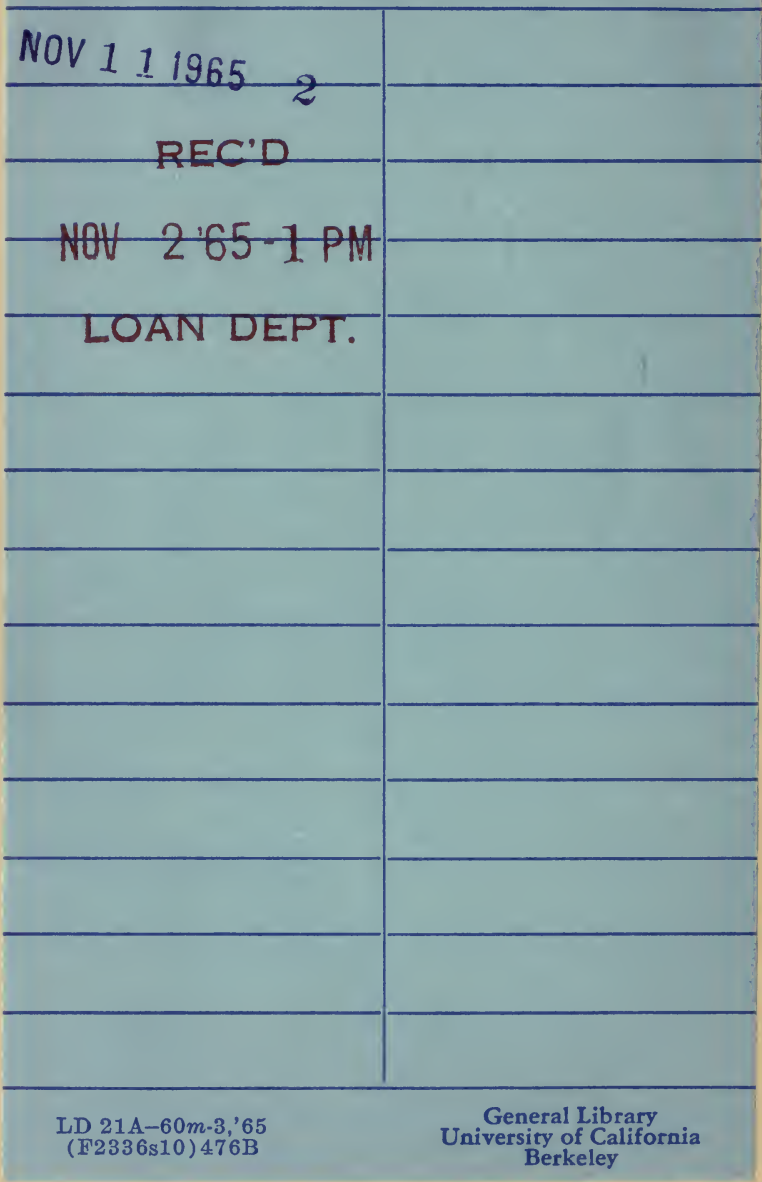





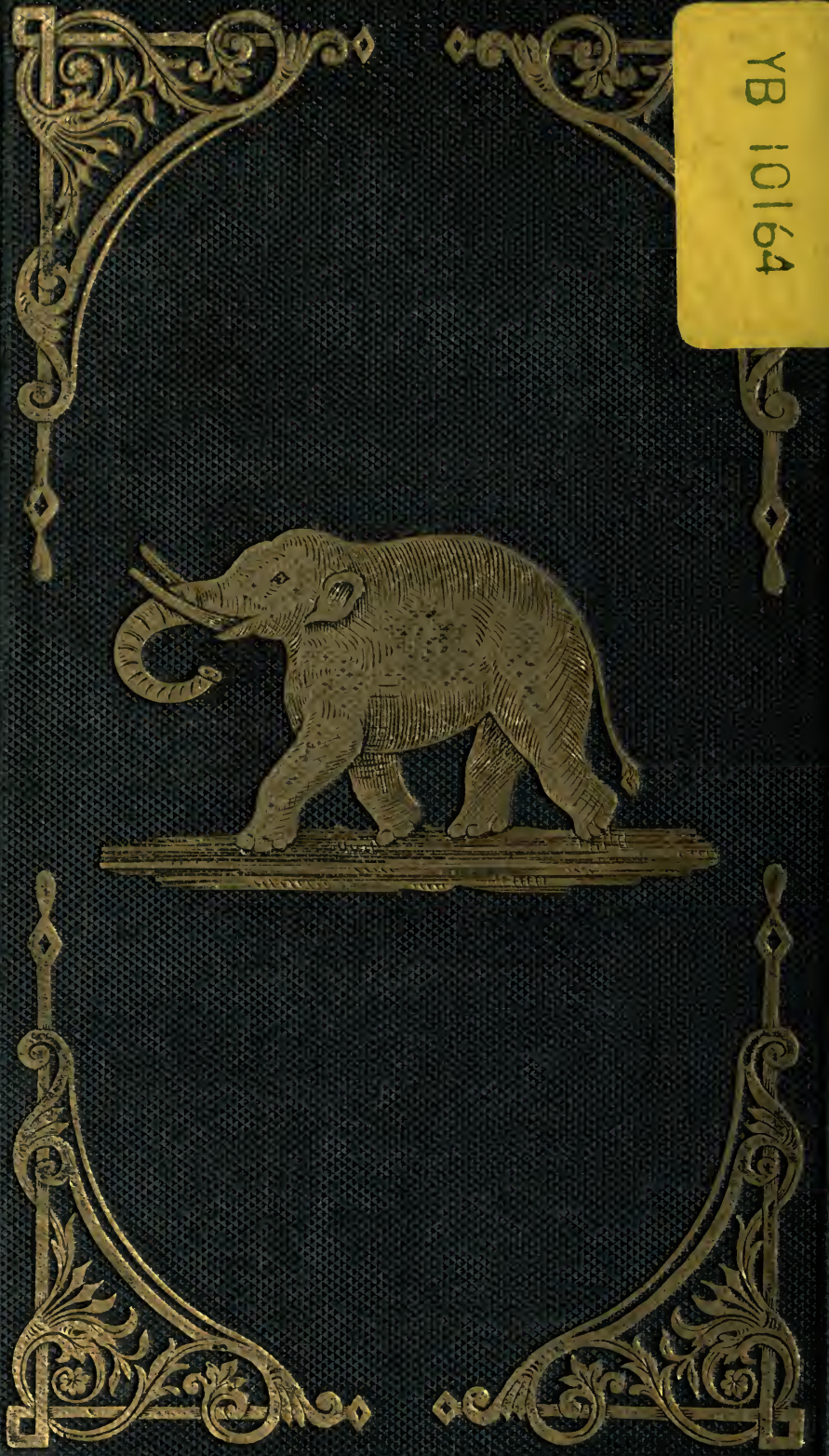

